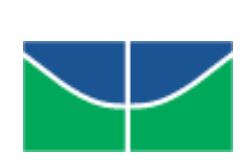

Universidade de Brasília

Faculdade de Economia, Administração, Contabilidade e Ciência da Informação e Documentação - FACE

Programa de Pós-Graduação em Administração - PPGA

Aline Gonçalves Cabeceira

\title{
TRANSPARÊNCIA E CONTROLE SOCIAL: OS IMPACTOS DO SICONV NA RELAÇÃO ESTADO E TERCEIRO SETOR
}


Aline Gonçalves Cabeceira

\section{TRANSPARÊNCIA E CONTROLE SOCIAL: OS IMPACTOS DO SICONV NA RELAÇÃO ESTADO E TERCEIRO SETOR}

Monografia apresentada ao Departamento de Administração da Faculdade de Economia, Administração, Contabilidade e Ciências da Informação e Documentação - FACE, da Universidade de Brasília, como requisito parcial à obtenção do título de Especialista em Orçamento e Finanças.

Orientador: Prof. Dr. Eduardo Raupp de Vargas

Brasília - DF 


\section{AGRADECIMENTOS}

A Deus, o criador de todos e tudo, o grande pesquisador e solucionador.

Agradeço ao meu marido, Juliano Costa Couto, pelo companheirismo, dedicação e incentivo.

Aos colegas de trabalho do Serviço Federal de Processamento de Dados do Governo Federal - SERPRO e da Secretaria do Tesouro Nacional - STN, pela ajuda e apoio para navegar, com orientação, na infindável rede de informações que é o Governo Federal.

Ao professor e orientador Eduardo Raupp de Vargas, pelas muitas contribuições ao longo da pesquisa e a todos os outros professores que também contribuíram para o meu crescimento profissional e pessoal.

Aos colegas de turma, que compartilharam dos vários momentos experimentados até a conclusão deste trabalho e me apoiaram em todos eles. 


\section{RESUMO}

Este trabalho é um estudo sobre o processo de transferência voluntária de recursos do Governo Federal para o terceiro setor, que nos sistemas de governo são identificados como entidades privadas sem fins lucrativos. O processo estudado foi implementado com a publicação do Decreto 6.170, de 25 de julho de 2007, da Portaria Interministerial 127, de 29 de maio de 2008 que resultou na implantação do Sistema de Gestão de Convênios e Contratos de Repasse - SICONV. Com base em literatura científica, foram caracterizados a transparência e o controle social no atual modelo de gestão pública e a inserção do terceiro setor nesse cenário. A pesquisa científica, qualitativa e de natureza descritiva, realizada por meio de pesquisa documental, deu base para a descrição do processo evidenciando suas alterações operacionais e a preocupação do Governo com a transparência e controle do mesmo. Ao final do trabalho conclui-se que existe legislação adequada para a orientação do processo de transferência voluntária e que a implantação o Sistema de Gestão de Convênios e Contratos de Repasse - SICONV facilita e agiliza esse processo, além de criar um canal de iteração entre o governo e a sociedade. Contudo, persiste a necessidade de se capacitar o cidadão comum para que esse, juntamente com o terceiro setor, possa exercer o controle social.

Palavras-chave: Transparência. Controle. Transferências Voluntárias.Terceiro Setor. 


\section{LISTA DE QUADROS}

Quadro 1 - Segmentação do Estado em Setores....... ...................................15

Quadro 2 - Fonte de evidências: pontos fortes e pontos fracos...........................35

Quadro 3 - Categorização da Transparência ………………….....................36

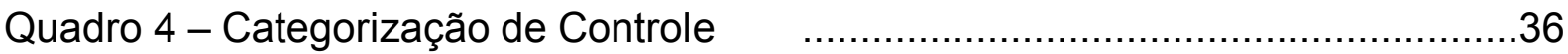




\section{LISTA DE FIGURAS}

Figura 1 - Esquema de controle social na Administração Pública......................... 26

Figura 2 - Fluxo Operacional do SICONV ...................................................41

Figura 3 - Fluxo Operacional do SICONV - Módulo de Celebração de Convênio....42

Figura 4 - Fluxo Operacional do SICONV - Módulo de Execução e Prestação de

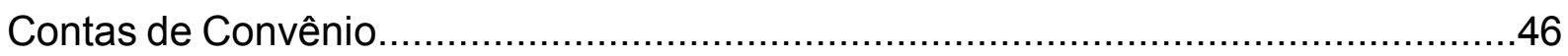




\section{LISTA DE SIGLAS}

AC - Análise de Conteúdo

BNDES - Banco Nacional de Desenvolvimento Econômico e Social

MPOG - Ministério do Planejamento, Orçamento e Gestão

SERPRO - Serviço Federal de Processamento de Dados do Governo Federal

SIAFI - Sistema Integrado de Administração Financeira

SICONV - Sistema de Gestão de Convênios e Contratos de Repasse

SOF - Secretaria de Orçamento Federal

TCU - Tribunal de Contas da União

TV - Transferências Voluntárias

CF/1988 - Constituição Federal de 1988 


\section{SUMÁRIO}

1. INTRODUÇÃO

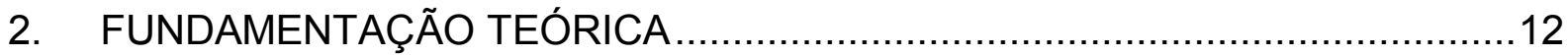

2.1. EVOLUÇÃO DA ADMINISTRAÇÃO PÚBLICA BRASILEIRA E A PARTICIPAÇÃO DAS ORGANIZAÇÕES SOCIAIS NESSE CONTEXTO .........12

2.1.1. O MODELO GERENCIAL.................................................12

2.1.2. A NOVA ADMINISTRAÇÃO PÚBLICA NO BRASIL .....................14

2.2. O PAPEL DO TERCEIRO SETOR NAS POLÍTICAS PÚBLICAS

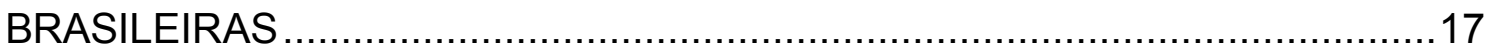

2.2.1. CONCEITUANDO O TERCEIRO SETOR .......................................17

2.2.2. TERCEIRO SETOR NAS POLÍTICAS PÚBLICAS ..............................19

2.3. A TRANSPARÊNCIA E O CONTROLE SOCIAL .................................21

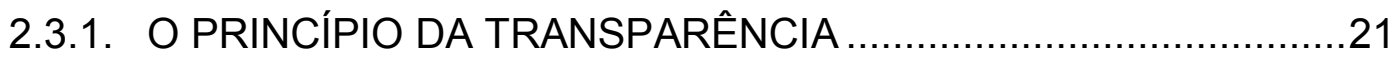

2.3.2. CONCEITUANDO O CONTROLE SOCIAL................................22

2.3.3. TRANSPARÊNCIA E CONTROLE SOCIAL NO ATUAL MODELO

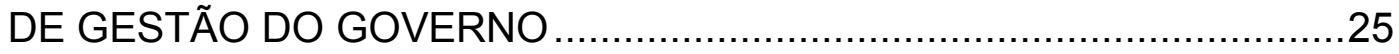

2.3.4. FORTALECIMENTO DO CONTROLE SOCIAL COMO RESPOSTA ÀS DIFICULDADES DA REFORMA IMPLANTADA .............................27

2.4. SISTEMAS DE INFORMAÇÃO E CONTROLE SOCIAL ...........................29

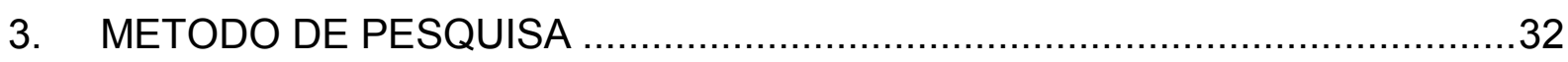

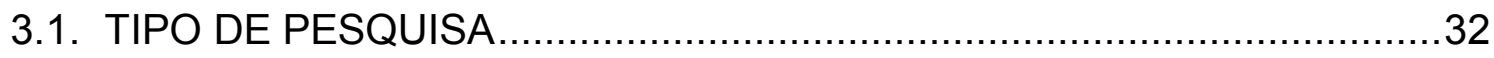

3.2. AMOSTRA DA PESQUISA E COLETA DE DADOS ................................33

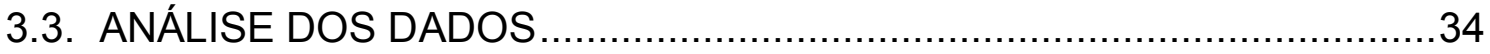

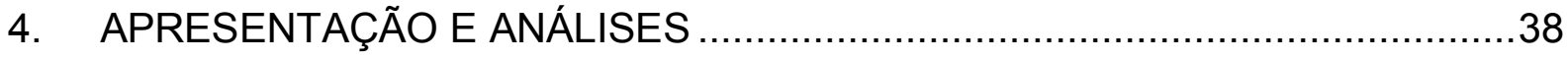

4.1. O PROCESSO DE TRANSFERÊNCIA VOLUNTÁRIA E O SICONV .......38

4.1.1. DETALHAMENTO DAS ATIVIDADES, EXECUTADAS PELO CONVENENTE, REFERENTES AO PROCEDIMENTO DE CELEBRAÇÃO DE CONVÊNIOS

4.1.2. DETALHAMENTO DAS ATIVIDADES, EXECUTADAS PELO CONVENENTE, REFERENTES AOS PROCEDIMENTOS DE EXECUÇÃO E PRESTAÇÃO DE CONTAS DE CONVÊNIOS 
4.1.3. ANÁLISE DAS PRINCIPAIS ALTERAÇÕES PROPOSTAS PELO DECRETO No 6.170/2007 E PELA PORTARIA INTERMINISTERIAL No 127/2008 À INSTRUÇÃO NORMATIVA No 01/1997.....................................49 4.2. A PREOCUPAÇÃO DO ESTADO QUANTO A TRANSPARÊNCIA E

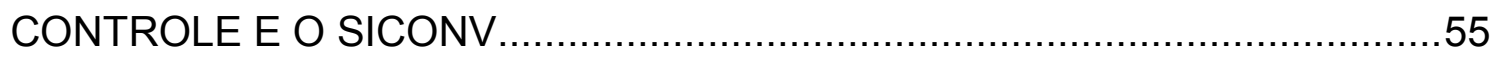

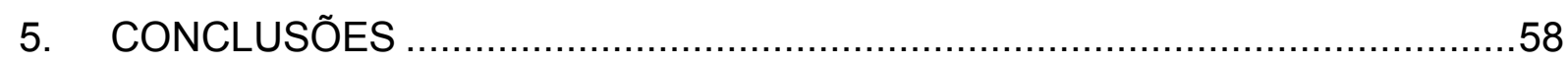

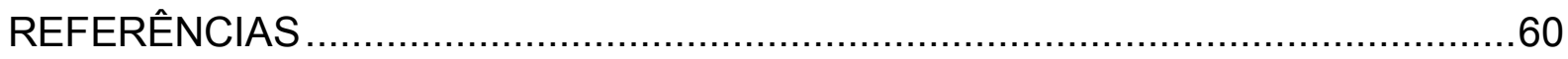




\section{INTRODUÇÃO}

O debate sobre corrupção e gasto ineficiente dos recursos públicos vem se intensificando na agenda dos governos, dos estudiosos e da sociedade civil. A ineficiência do gasto público afeta de forma negativa a efetividade das políticas públicas e o crescimento econômico do país. É por isso que o controle e a transparência do gasto público tornaram-se uma exigência da sociedade.

Dentre as questões discutidas uma que tem sido alvo de fundadas críticas é o controle e a transparência das transferências voluntárias de recursos públicos federais (BRASIL, 2008i). Colaço-Alves e Sodré (2008) evidenciam a correlação entre recebimento de recursos de emendas parlamentares, descentralização de recursos através de transferências voluntárias, e corrupção no âmbito municipal. Ferreira e Bugarin (2007) comprovam outra forma enviesada da utilização das transferências voluntárias, a utilização desse tipo de recurso para influenciar o comportamento eleitoral em municípios.

Estudos publicados pela Secretaria de Orçamento Federal - SOF (BRASIL, 2003) afirmam que o orçamento do Governo Federal é afetado pelo excessivo grau de vinculação de receitas e pelo elevado nível de despesas constitucionais e legalmente obrigatórias. Essa realidade faz com que as transferências voluntárias, que são realizadas de forma discricionária, assumam papel muito importante nas relações políticas e sociais brasileiras.

Neste ponto, outro aspecto observado por Ferreira e Bugarin (2007) chama atenção, refere-se ao volume das transferências voluntárias realizadas no período de 1995 a 2000, que segundo o autor é significante e crescente.

Frente ao cenário apresentado, para garantir transparência e aperfeiçoar o controle da utilização de recursos repassados pela União, o Governo Federal iniciou um conjunto de ações que objetivam regularizar o processo de transferências voluntárias. Dentre essas ações, destaca-se a publicação de decretos e portarias governamentais que regulamentam o assunto e tornam obrigatória da utilização do Sistema de Gestão de Convênios e Contratos de Repasse - SICONV, onde devem 
ser registrados todos os atos relativos ao processo de operacionalização das transferências voluntárias.

Essas ações buscam cumprir o exigido pelos princípios constitucionais de eficiência e publicidade dos atos públicos e tem como objetivo gerar a transparência e o controle que são necessários a qualquer processo na esfera da Administração Pública. No entanto, essas medidas podem impactar no sistema de cooperação firmado entre a União e entidades governamentais e/ou entidades privadas sem fins lucrativos, comprometendo a cooperação entre essas entidades.

Esse estudo buscou identificar quais impactos a implantação do SICONV gerou na relação do Estado com o terceiro setor. Esse aspecto se torna importante uma vez que, segundo Pinto (2006), a partir das últimas décadas do século XX, durante o movimento de descentralização do Estado, entidades privadas sem fins lucrativos passaram a se apresentar como parceiras do Estado na condução de políticas públicas, e por vezes como substituta desse em áreas específicas.

Milani (2008) também afirma que os anos 90 foram marcados pela institucionalização da consulta da sociedade civil organizada nos processo de formulação de políticas públicas locais. Milani (2008) explicita que:

\footnotetext{
Há uma demanda claramente formulada por atores da sociedade civil em prol da renovação das relações governo-sociedade e de uma redefinição da representação política, uma vez que a representação tradicional se encontra cada vez mais distante da vontade dos representados. (MILANI, 2008, p. 561).
}

O crescimento da participação da sociedade civil nas políticas públicas também se fez perceber pelo crescimento do número de convênios celebrados entre o governo e essas entidades e pelo aumento do volume de recursos repassados a essas instituições.

Poucos estudos foram realizados sobre esse tema e, em sua maioria, se dedicam a analisar as características e influências causadas por repasses realizados para estados, distrito federal e municípios, apesar das transferências voluntárias também serem realizadas para entidades não-governamentais.

Elaborar um estudo sobre o processo de transferências voluntárias de recursos públicos federais, especificando os repasses realizados para entidades privadas sem fins lucrativos, também conhecidas como organizações não- 
governamentais, permitirá a ampliação do debate científico sobre o tema e pode contribuir para a evolução do processo de cooperação governo e sociedade civil.

O objetivo geral deste estudo é identificar e analisar os impactos operacionais, referentes aos procedimentos necessários para a celebração de convênios, causados pela implantação do SICONV no relacionamento do Governo Federal com entidades não-governamentais que participam de ações de interesse público e são financiadas por transferências voluntárias do Governo Federal.

Para atingir esse objetivo discutiu-se a participação do terceiro setor nas políticas públicas brasileiras e sua inserção no modelo de gestão pública, caracterizou-se a transparência e o controle no modelo de gestão do governo. Também foi abordada a importância dos sistemas de tecnologia da informação como instrumentos de transparência e controle.

Após a formação desse lastro teórico foi descrito o processo de transferência voluntária proposto na nova legislação, que culminou na obrigatoriedade do uso do SICONV. Por fim foram identificados os impactos operacionais causados pela implantação do SICONV e a preocupação do Estado em gerar transparência nesse processo. Finalmente, são apresentadas as considerações finais. 


\section{FUNDAMENTAÇÃO TEÓRICA}

Neste capítulo foi construída uma revisão conceitual necessária para o entendimento e contextualização do tema objetivo deste trabalho.

Inicialmente, foram apresentados os modelos de gestão pública vivenciados na atualidade no cenário internacional e nacional. Ainda nesse contexto foi inserida uma perspectiva do papel do terceiro setor no modelo de gestão pública adotado no Brasil. Na seqüência foram abordados os conceitos de transparência e controle no âmbito do Poder Público Brasileiro. Também foi discutida a contribuição de sistemas de informação para a prática da transparência e do controle. Por fim, objetiva-se esclarecer a necessidade de se conhecer esses conceitos para a evolução deste trabalho.

\subsection{EVOLUÇÃO DA ADMINISTRAÇÃO PÚBLICA BRASILEIRA E A PARTICIPAÇÃO DAS ORGANIZAÇÕES SOCIAIS NESSE CONTEXTO}

Nessa seção foi discutido o atual modelo de gestão pública adotado no Brasil, e como o terceiro setor se insere nesse contexto.

\subsubsection{O MODELO GERENCIAL}

Do pós-guerra até os anos 80 prevaleceu como doutrina de governo dominante a baseada no keynesianismo, ou seja, uma forma de governar baseada na intervenção do Estado sobre o mercado. Esse modelo também conhecido como Estado de bem-estar pregava a ampliação da ação Estatal e por conseguinte dos 
gastos governamentais como forma de estimular o crescimento econômico, gerar empregos e promover o bem estar social.

No entanto, segundo Paula (2007), no início do século XXI a crise do Estado e a internacionalização de problemas econômicos como a inflação, a estagnação e choques do petróleo favoreceram e justificaram a disseminação da proposta de uma nova gestão pública com base em propostas neoliberais e neoconservadoras.

Isso significa dizer que, em contraposição ao modelo anterior, o novo papel do Estado implicaria na redução de sua intervenção no setor privado e na sociedade, apenas determinando e arbitrando as regras do jogo de forma a garantir a existência do livre-mercado.

Paula (2007) destaca que também nesse contexto emergiu uma nova cultura gerencial, o movimento gerencialista. Esse movimento pregava o enxugamento das empresas, a reengenharia e a administração da qualidade total entre outros, e transformou a administração de empresas em um referencial para o setor público.

Ao novo modelo de gestão pública, que aliou as idéias neoliberais, neoconservadoras e o gerencialismo, denominou-se de a Nova Administração Pública, e sua emergência ocorreu na década de 80. Para materializar essa experiência pode ser utilizado o caso do Reino Unido, mais especificamente a era Thatcher, de 1979 a 1987. Segundo Paula (2007), esse governo seguiu as recomendações neoliberais e estabeleceu medidas administrativas e organizativas que deram as seguintes características a nova administração pública do país:

- descentralizacão do aparelho do Estado, que separou as atividades de planejamento e execução do governo e transformou as políticas publicas em monopólio dos ministérios;

- privatização das estatais;

- terceirização dos serviços públicos;

- regulação estatal das atividades públicas conduzidas pelo setor privado;

- uso de idéias e ferramentas gerenciais advindas do setor privado (PAULA, 2007, p.47).

Após a implantação desse modelo no Reino Unido, em 1980, suas bases ideológicas foram difundidas para outros países. Apesar de sua difusão, de acordo com Paula (2007), o exame da literatura permite apontar as seguintes limitações da Nova Administração Pública: 
- Formação de uma nova elite burocrática;

- centralização do poder nas instancias executivas;

- inadequação da utilização de técnicas e práticas advindas do setor privado no setor público;

- dificuldade de lidar com a complexidade dos sistemas administrativos e a dimensão sociopolítica da gestão;

- incompatibilidade entre a lógica gerencialista e o interesse público (PAULA, 2007, p.82).

Com base nas constatações descritas, tomaram corpo novos movimentos internacionais com o objetivo de dar nova roupagem ao neoliberalismo. Os movimentos Reinventando o Governo, a Terceira Via e a Governança Progressista, que Segundo Paula (2007), preservam as premissas econômicas e morais do neoliberalismo.

Dessa forma, os governos continuam diminuindo seu papel na área social, cortando gastos, transferindo serviços para o setor privado, focalizando a atenção apenas nos segmentos mais necessitados da população e abrindo espaço para que organizações filantrópicas atuem em setores que pouco são atraentes para o mercado.

\subsubsection{A NOVA ADMINISTRAÇÃO PÚBLICA NO BRASIL}

As propostas de reforma da administração pública chegaram ao Brasil nos anos 90 como um reflexo das experiências neoliberais ocorridas no Reino Unido, Estados Unidos e outros países, sob a denominação de administração gerencial.

O desejo de mudança, direcionado pelas idéias do gerencialismo, foi materializado no Brasil em 1995, com o Plano Diretor da Reforma do Estado. Este plano fora estruturado pelo Ministério da Administração Federal e Reforma do Estado, chefiado pelo então Ministro Luiz Carlos Bresser Pereira.

De acordo com Paula (2007), a análise de documentos publicados até 1993 mostra que as justificativas para a implantação desse plano estavam vinculadas principalmente a crise de legitimidade e governabilidade que o Estado brasileiro passava. Essa crise era causada pelas crises fiscal, do modo de intervenção do Estado e a crise de sua forma burocrática de administração. Além dessas 
constatações havia recomendações do Consenso de Washington, e outros organismos internacionais, que indicavam a necessidade da reforma.

Em 1998 foi promulgada a emenda da reforma, que efetivou as mudanças estruturais necessárias para a implantação do Plano Diretor. Nesse plano as atividades do governo foram divididas em exclusivas do Estado e não exclusivas do Estado.

As atividades exclusivas do Estado estavam ligadas a legislação, regulação, fiscalização, fomento e formulação de políticas públicas. As não exclusivas tinham caráter competitivo e atividades auxiliares e de apoio, e seriam realizadas pelo setor privado ou por organizações sociais.

Bresser-Pereira (2000) define os serviços não-exclusivos como os serviços que o Estado provê, mas que não envolvem o poder extroverso do Estado, podendo ser oferecidos pelo setor privado e pelo público não-estatal.

Para Ramos (1997), uma característica fundamental da reforma do Estado foi a adoção do modelo conceitual de segmentação do Estado em setores. Segundo o autor os setores adotados na reforma brasileira foram:

\begin{tabular}{l|l}
\multicolumn{1}{c|}{ Setor Estado } & \multicolumn{1}{c}{ Atribuições } \\
\hline Núcleo estratégico & $\begin{array}{l}\text { Define as leis e políticas e cobra seu cumprimento, ou } \\
\text { seja, é o setor onde as decisões estratégicas são } \\
\text { tomadas. }\end{array}$ \\
\hline Atividades exclusivas & $\begin{array}{l}\text { É o setor onde são prestados os serviços que só o Estado } \\
\text { pode realizar, e onde se exerce o poder extroverso do } \\
\text { Estado. }\end{array}$ \\
\hline Serviços não-exclusivos & $\begin{array}{l}\text { É o setor onde o Estado atua simultaneamente com outras } \\
\text { organizações públicas não-estatais e privadas; as } \\
\text { instituições aqui não possuem poder de Estado, mas este } \\
\text { está presente, pois a prestação desses serviços envolve } \\
\text { direitos humanos fundamentais. }\end{array}$ \\
\hline Produção para o mercado & $\begin{array}{l}\text { É a área de atuação das empresas caracterizadas pelas } \\
\text { atividades econômicas voltadas para o lucro. }\end{array}$ \\
\hline
\end{tabular}

Quadro 1 - Segmentação do Estado

Fonte: Ramos (1997, p. 81).

Apesar da implantação desse Plano Diretor, de acordo com Paula (2007), no Brasil a reforma da administração pública dos anos 90 se orientou por duas vertentes políticas, a de cunho gerencial e a de cunho societal.

O movimento societal tem como cerne a participação social, e se fortaleceu no Brasil no período da Constituinte, após o fim da ditadura, momento em que se buscava um novo modelo para as relações entre o Estado e a sociedade. $O$ 
fortalecimento do papel da sociedade era solicitado pela nação e foi nesse cenário que os sindicatos, pastorais, partidos políticos de esquerda e organizações nãogovernamentais, entre outros, passaram a demandar solicitações ao Estado.

Dagnino (2004) fortalece a idéia de legitimação da vertente societal pela formalização desta na Constituição de 1988, que consagrou a participação da sociedade civil no processo da gestão pública como forma de alargar a democracia.

Paula (2007) constata que a vertente gerencial foi implantada pela esfera Federal, através do Plano Diretor de 1998. Já a vertente societal tem inspirado experiências alternativas da gestão pública, e são realizadas no âmbito local, ou seja, na esfera Municipal.

Vale destacar que ambas as vertentes dizem buscar um modelo de gestão que se opõem ao modelo burocrático e que buscam a ampliação da democracia através do aumento da participação da sociedade organizada na administração pública. No entanto, na análise de Paula (2007) tanto a abordagem gerencial, quanto a societal ainda não atingiram esse objetivo.

Paula (2007) esclarece que a abordagem gerencial desapontou com relação ao crescimento econômico e ao progresso social. E em virtude dessa realidade nas eleições presidenciais de 2002 foi vitoriosa a aliança política com abordagem societal. No entanto, para Paula (2007), mesmo com essa mudança o que se observa é a continuidade das práticas gerencialista, pois as duas vertentes não proporcionaram a efetiva participação social. No caso da vertente gerencial isso se explica pela simples continuidade do modelo administrativo. Para a abordagem societal falta a definição de uma proposta para a organização do aparelho do Estado.

Em oposição ao parecer de Paula (2007), para Bresser-Pereira (2000) a reforma gerencial no Brasil foi um projeto bem sucedido. Para ele, a definição em lei das agências reguladoras e executivas e o estabelecimento das primeiras organizações sociais materializam o sucesso da reforma. Além desses fatos, ele afirma que a adoção da gestão pela qualidade no serviço público revela uma mudança da cultura burocrática para uma cultura gerencial. 


\subsection{O PAPEL DO TERCEIRO SETOR NAS POLÍTICAS PÚBLICAS BRASILEIRAS}

A idéia de uma sociedade mais participativa se fortaleceu a partir da Constituição de 1988, e se tornou uma forma de ampliação da democracia no Brasil.

Nessa seção foi caracterizado o conceito de terceiro setor e discutido o seu papel nas políticas públicas brasileiras.

\subsubsection{CONCEITUANDO O TERCEIRO SETOR}

De acordo com Ferreira e Ferreira (2006), ainda não foi encontrada uma via de aceitação comum para a definição conceitual do termo terceiro setor e também não há consenso em relação às organizações que o integram. Os autores explicam que essa indefinição ocorre em virtude do terceiro setor ser um fenômeno social recente e por isso o grau de informação e conhecimento sistematizado sobre este ainda é insipiente.

Modesto (1997) concorda que existe confusão sobre o papel organizações sociais como parceiras do Estado, e afirma que as dúvidas iniciam-se sobre a própria identificação do que sejam as organizações sociais.

Segundo Fernandes (1994 apud FERREIRA e FERREIRA, 2006, p.13) outra forma de explicar essa confusão é o fato da construção do terceiro setor, no Brasil, ter ocorrido através de uma certa imposição de organismos nacionais e internacionais, não sendo discutida de forma adequada a formalização deste setor nem mesmo entre as organizações que atuam sob essa designação. Para complementar o acima descrito, é valido citar que Montaño (2002 apud FERREIRA e FERREIRA, 2006, p.13) afirma que o termo terceiro setor tem origem norteamericana. 
Apesar da indefinição sobre os aspectos conceituais do terceiro setor e as organizações que o compõem, alguns autores, e mesmo órgãos do governo, empenha esforços para formular definições sobre este setor.

Neste trabalho serão citadas as definições de Modesto (1997) e do Banco Nacional de Desenvolvimento Econômico e Social - BNDES.

Modesto (1997), em seus estudos, define as organizações sociais da seguinte maneira:

as organizações sociais são pessoas jurídicas de direito privado, sem fins lucrativos, voltadas para atividades de relevante valor social, que independem de concessão ou permissão do Poder Público, criadas por iniciativas particulares segundo modelo previsto em lei, reconhecidas, fiscalizadas e fomentadas pelo Estado. (MODESTO, 1997, p.31)

Em complemento ao conceito por ele definido, Modesto (1997) afirma serem as organizações sociais uma forma de parceria do Estado com instituições privadas de fins públicos ou uma forma de participação popular na gestão pública. $O$ autor enfatiza que o termo organização social é um título concedido pelo Poder Público através de ato formal, facultativo e eventual a entidades privadas, fundações ou associações sem fins lucrativos.

De acordo com a publicação do Relato Setorial $n^{\circ} 3$ de julho de 2001 do BNDES o terceiro setor pode ser definido conforme abaixo:

Constitui-se na esfera de atuação pública não-estatal, formado a partir de iniciativas privadas, voluntárias, sem fins lucrativos, no sentido do bem comum. Nesta definição, agregam-se, estatísticas e conceitualmente, um conjunto altamente diversificado de instituições, no qual incluem-se organizações não governamentais, fundações e institutos empresariais, associações comunitárias, entidades assistenciais e filantrópicas, assim como várias outras instituições sem fins lucrativos. (BNDES, 2001, p. 4)

Na opinião dos autores pesquisados, apesar da indefinição do termo, na sociedade contemporânea brasileira o terceiro setor é considerado um importante instrumento de apoio de governos no estabelecimento de políticas públicas para a área social e na execução e controle de projetos sociais através da liberação de verbas na forma de parcerias, convênios e de renuncias fiscais. 


\subsubsection{TERCEIRO SETOR NAS POLÍTICAS PÚBLICAS}

Conforme explicitado, nas duas vertentes de governo adotadas no Brasil, na gerencial e na societal, se observa a legitimação da participação de organizações sociais nas políticas públicas.

Essa realidade pode ser observada também no aparato jurídico produzido sobre o assunto. Um exemplo, segundo Modesto (1997), é a Lei Orgânica da Assistência Social, Lei $n^{\circ} 8.742$, de 7/12/1993, que dispõem sobre mecanismos de cooperação dos particulares nos projetos prioritários de assistência social. No artigo 26 reconhece três categorias participantes do sistema de cooperação: organismos governamentais, não governamentais e da sociedade civil.

Segundo Bresser-Pereira (2000), Ministro da reforma gerencial no Brasil, as organizações sociais surgiram durante a reforma e compuseram o chamado setor público não-estatal. Esse setor é autorizado pelo Parlamento a receber dotação orçamentária do Tesouro com o objetivo de executar serviços sociais e científicos não exclusivos do Estado. Bresser-Pereira (2000) afirma que o núcleo estratégico do Estado seria considerado como atividade exclusiva do Estado.

Modesto (1997) enfatiza que no modelo proposto na reforma de 1995 as organizações sociais não tem qualquer espécie de prerrogativa de direito público, não estão sujeitas a supervisão ou tutela da administração pública, respondendo apenas pela execução e regular aplicação dos recursos públicos vinculados ao acordo ou contrato de gestão firmado com o Poder Público.

Paula (2007, p.147) afirma que "na reforma o tratamento da sociedade civil como instituição e não como agente já sinaliza o caráter limitado da participação social na estrutura e dinâmica governamental da vertente gerencial". Para Osborne e Gaebler (1994 apud PAULA, 2007, p.63) persiste a idéia de participação comunitária na execução dos serviços públicos e praticamente inexistem referências sobre a inserção social na formulação de políticas públicas.

Esse aspecto de participação limitada da sociedade nas políticas públicas pode ser confirmado no artigo publicado por Marianne Nassuno (1997), que em 1997 era especialista em políticas públicas e gestão governamental no Ministério da Administração Federal e Reforma do Estado. Em seu artigo sobre a organização dos 
usuários e sua participação na gestão e controle das organizações sociais, a autora diz serem os usuários dos serviços públicos auxiliares dos políticos na supervisão e garantia da implementação das políticas por eles definidas.

Outro aspecto, levantado por Barreto (1999 apud PAULA, 2007, p.148) sobre a atual participação das organizações sociais nas políticas públicas, é que Bresser pretendia construir uma esfera pública não-estatal na qual a representação social se daria através de representantes da comunidade nos órgãos colegiados de deliberação superior. No entanto, esse mecanismo não atraiu número significativo de entidades da sociedade civil, pois o formato institucional das organizações sociais e a estrutura do aparelho de Estado não permitem maior inserção popular no processo decisório e na formulação de políticas públicas.

Segundo Dagnino (2004), após uma análise mais profunda das propostas políticas das duas vertentes políticas existentes no Brasil é possível verificar que a coincidência na exigência de uma sociedade civil ativa e propositiva é na verdade antagônica. A similaridade fica apenas no nível do discurso.

Para Paula (2007) e Dagnino (2004) a solicitação de participação social que emergiu da luta contra o regime militar e foi empreendida por setores da sociedade civil e formalizada na Constituição de 1998 estava além da simples execução de políticas públicas. A necessidade estava em fazer a sociedade participar da definição das políticas, que é o cerne da vertente societal, no entanto atualmente essa definição esta sob o controle do Estado, na figura do Executivo.

A análise do art. 20 da lei 9.637 de 15 de maio de 1998, que dispõem sobre as regras para que entidades se qualifiquem como organizações sociais e passem a executar atividades dirigidas ao ensino, pesquisa científica, desenvolvimento tecnológico, proteção e preservação do meio ambiente, cultura e saúde, deixa claro seu foco gerencialista, uma vez que trata o cidadão como cidadão-cliente e dá ênfase no acompanhamento dos resultados das organizações através de atingimento de resultados qualitativos e quantitativos, não formalizando o mecanismo de controle social das ações. 


\subsection{A TRANSPARÊNCIA E O CONTROLE SOCIAL}

É fato que as transformações ocorridas em função das reformas administrativas brasileiras indicam o fortalecimento e ampliação do controle social, no entanto pouco se evoluiu nesse caminho.

Nessa seção serão caracterizados os conceitos de transparência e controle, e se discutirá a sua contextualização no atual modelo de gestão do Brasil.

\subsubsection{O PRINCÍPIO DA TRANSPARÊNCIA}

Matias-Pereira (2008) diz ser a transparência do Estado a possibilidade de acesso do cidadão à informação governamental. Segundo o autor, a transparência tornou-se uma perspectiva democratizante surgida no fim do período de autoritarismo, em 1985. No entanto, ainda hoje, a transparência das ações do governo está longe do ideal.

Para Pimenta (1998 apud SILVA, 2001, p. 57) existem oito princípios que devem ser considerados para a valorização do controle social como estratégia da Administração Pública. Esses princípios são a desburocratização, descentralização, transparência, accountability, ética, profissionalismo, competitividade e enfoque no cidadão.

De acordo com Pimenta (1998 apud SILVA, 2001, p. 57) todos esses princípios estão ligados entre si. Se a Administração Pública se torna mais desburocratizada, descentralizada e flexível deve-se dar maior transparência às suas ações, para poder controlá-las. O controle se torna imprescindível, pois a flexibilização, muitas vezes, abre espaço para a má utilização de recursos e corrupção, daí a necessidade da ética e da accountability. Em conjunto com tudo isso, o profissionalismo, o estímulo à competitividade e o foco no cidadão estabeleceriam uma estratégia que, apesar de ser de longo prazo, seria adequada para uma transformação efetiva da Administração Pública. 
Pimenta (1998 apud SILVA 2001, p. 57) diz ser a transparência um princípio fundamental para substituir controles meramente burocráticos por controles sociais.

\subsubsection{CONCEITUANDO O CONTROLE SOCIAL}

De acordo com Silva (2001), existem algumas maneiras de se classificar as espécies de controle. Para esse autor, o critério de classificação mais geral é o que utiliza o órgão que exerce o controle para definir o tipo de controle. Nessa forma de classificar, o controle pode ser administrativo, legislativo ou judicial.

O controle administrativo é exercido pelo poder de fiscalização e correção que a Administração Pública exerce sobre seus próprios atos. O controle legislativo é exercido sob duas formas, o controle político e o financeiro. O primeiro é previsto na Constituição Federal com competências exclusivas do poder legislativo, que atua sobre os atos da Administração Pública em sentido amplo. O controle financeiro, também previsto na CF, é definido como a competência do Congresso Nacional na fiscalização contábil, financeira, orçamentária, operacional e patrimonial da União. O controle Judicial é baseado no Estado de direito e no princípio da legalidade dos atos públicos, ou seja, o judiciário deve apreciar, com força de coisa julgada, a lesão ou ameaça de lesão a direitos individuais ou coletivos, qualquer que seja o autor da lesão, mesmo que seja o poder público.

Silva (2001) define outros tipos de controle, são eles:

- Controle Interno e Externo: classificação relacionada ao fato de o órgão que realiza o controle ser um órgão interno ou não a estrutura do ente controlado. Se o controle é exercido por cada poder sobre seus próprios atos e agentes, o controle é interno. Já o controle de um poder sobre o outro, ou mesmo da administração direta sobre a indireta é o controle externo. Silva (2001) ressalta que o controle externo exercido pelo Congresso Nacional, auxiliado pelo Tribunal de Contas da União TCU, está previsto na CF de 1988, em seus artigos 70 e 72.

- Controle Prévio, Concomitante ou Posterior: classificação definida pelo momento em que o controle ocorre. Se o controle é exercido antes do ato produzir 
efeito ele é prévio. O controle posterior visa analisar, confirmar, corrigir ou desfazer um ato. $\mathrm{O}$ controle concomitante é o que ocorre durante a execução do ato, é o acompanhamento da ação.

- Controle com ênfase no processo ou no resultado da gestão: a distinção é feita na ênfase que o controle dá a um desses dois critérios. Silva (2001) ressalta que a noção desse tipo de controle surgiu com o modelo gerencial.

Bresser Pereira (1998 apud SILVA, 2001, p.30), em seu livro Reforma do Estado para a cidadania, define que existem três mecanismos de controle fundamentais, e esses são baseados na entidade que exerce o controle. Para esse autor os mecanismos de controle são o Estado, o mercado ou a sociedade civil. No Estado está incluído o sistema legal, no mercado o sistema econômico e na sociedade civil estão os grupos sociais.

Para Bresser (1998 apud SILVA, 2001, p.30), ainda existe o critério funcional para definir controle. Nesse critério define o controle hierárquico, exercido dentro das organizações; o controle social, exercido em termos políticos sobre as organizações e os indivíduos; e o controle econômico, exercido pelo mercado.

Destaca-se que, conforme explicitado nos parágrafos anteriores, no Brasil, o conceito de controle social, começou a se formalizar nas décadas de 80 e 90, em virtude do cenário político e social que o país vivia. Vale lembrar que foram nessas décadas que se consolidaram a reforma gerencial e a percepção da importância do fortalecimento da participação da sociedade civil como atora e (autora) no processo político brasileiro.

De acordo com Silva (2001), trabalhos recentes identificam o termo controle social como a possibilidade da atuação de grupos sociais (sociedade civil) por meio de qualquer uma das vias de participação democrática no controle das ações do Estado e dos gestores públicos.

Para Silva (2001) quando se junta à palavra controle o termo social dá-se um sentido da origem do controle. Na opinião desse autor falar em controle da Administração Pública é o mesmo que falar em controle social, uma vez que é para a sociedade que todos os entes públicos devem prestar contas, pois estes à representam.

Ferreira (2006) reforça a idéia acima descrita afirmando que atualmente o controle social é denominado accountability. De acordo com esse autor o conceito de accountability traduz-se na obrigação de prestação de contas do poder público 
perante a sociedade civil e às autoridades competentes. O autor também afirma que só há eficácia na prestação de contas do Poder Executivo para a sociedade se esta verdadeira mente exercer o controle social sobre governantes e burocracia estatal.

Ainda relacionado ao conceito de accountability, segundo Silva (2001), está a necessidade de haver a responsabilização dos gestores, destacando inclusive a necessidade de punição efetiva dos gestores que não sirvam à sua clientela de acordo com padrões normativos do governo democrático.

Segundo Silva (2001), no âmbito da Administração Pública, a finalidade do controle é garantir que os administradores públicos atuem de acordo com os princípios explícitos e implícitos da Constituição Federal. Para Silva (2001, p.24) esses princípios são "legalidade, moralidade, finalidade pública, motivação, impessoalidade, publicidade e, mais recentemente introduzido, o princípio da eficiência".

Matias-Pereira (2008) concorda que o controle dos gastos públicos seja orientado por princípios que o instituem o e regem. Para esse autor os princípios relacionados ao controle exercitado pelos órgãos encarregados de o realizarem são:

Princípio da Universalidade: Todos os gestores públicos estão submetidos ao controle.

Princípio da Totalidade: A totalidade do patrimônio público - dinheiro, bem e valores - está submetida ao controle.

Princípio da Legalidade: $O$ controle deve ter uma estreita obediência aos ditames legais que regem a sua atuação.

Princípio da Imparcialidade: As ações devem ser implementadas sem que se permita intromissão de questões de ordem política no desenvolvimento das atividades.

Princípio da Autonomia: Princípio essencial ao exercício do controle, tanto para garantir a sua existência como para viabilizar o exercício de suas atividades.

Princípio da Independência: $O$ controle está obrigado a manter independência em relação a todos os agentes políticos ou servidores públicos, qualquer que seja sua posição na escala hierárquica da Administração Pública. Controle da Legalidade: $O$ controle da legalidade refere-se à adequação da despesa e dos procedimentos a ela inerentes com a legislação que rege a matéria.

Controle da Legitimidade: Para ser aceita como legítima, a despesa deve ser orientada para a concretização do bem comum.

Controle da Economicidade: Esse princípio está relacionado ao exame da despesa do ponto de vista da obtenção de resultado a custo adequado.

Controle da Moralidade: Os atos administrativos devem estar contidos dentro da moralidade. (MATIAS-PEREIRA, 2008, p. 195-196) 


\subsubsection{TRANSPARÊNCIA E CONTROLE SOCIAL NO ATUAL MODELO DE GESTÃO DO GOVERNO}

$\mathrm{Na}$ análise de Matias-Pereira (2008), as tentativas de reforma da Administração Pública, realizadas após 1985, geraram uma crescente e preocupante desorganização nos centros decisórios do governo. Foi afetada a memória administrativa, bem como os sistemas de produção de informação essenciais para o processo decisório do governo. Essa realidade contribuiu para que a transparência do Estado, contida nos princípios constitucionais de 1988, permanecesse abaixo da expectativa da social gerada em 1990.

A reforma administrativa de 1995 implementou o modelo gerencial no Brasil. Para Loureiro e Fingermann (1992 apud SILVA, 2001, p. 26), a descentralização das atribuições do Estado, um dos objetivos da reforma, impôs a necessidade de uma participação cada vez maior da sociedade no controle da Administração.

Silva (2001), cita que Bresser Pereira, então ministro do Ministério da Administração Federal e Reforma do Estado pregava que após a reforma o controle deixaria de ser burocrático, de procedimentos, realizado pelo próprio administrador e por órgãos internos e externos e passaria a ser composto de quatro tipos de controle, são eles:

- Controle de resultados, a partir de indicadores de desempenho estipulados nos contratos de gestão.

- Controle contábil de custos, que pode ser entendido como elemento central do controle de resultados.

- Controle por quase-mercados ou competição administrada

- Controle social, pelo qual os cidadãos exercitam formas de democracia direta (SILVA, 2001, p.37).

De acordo com Silva (2001), no processo de controle administrativo e político do modelo gerencial a sociedade participaria de forma ativa e passiva. Para esclarecer essa afirmação o autor utiliza a seguinte figura: 


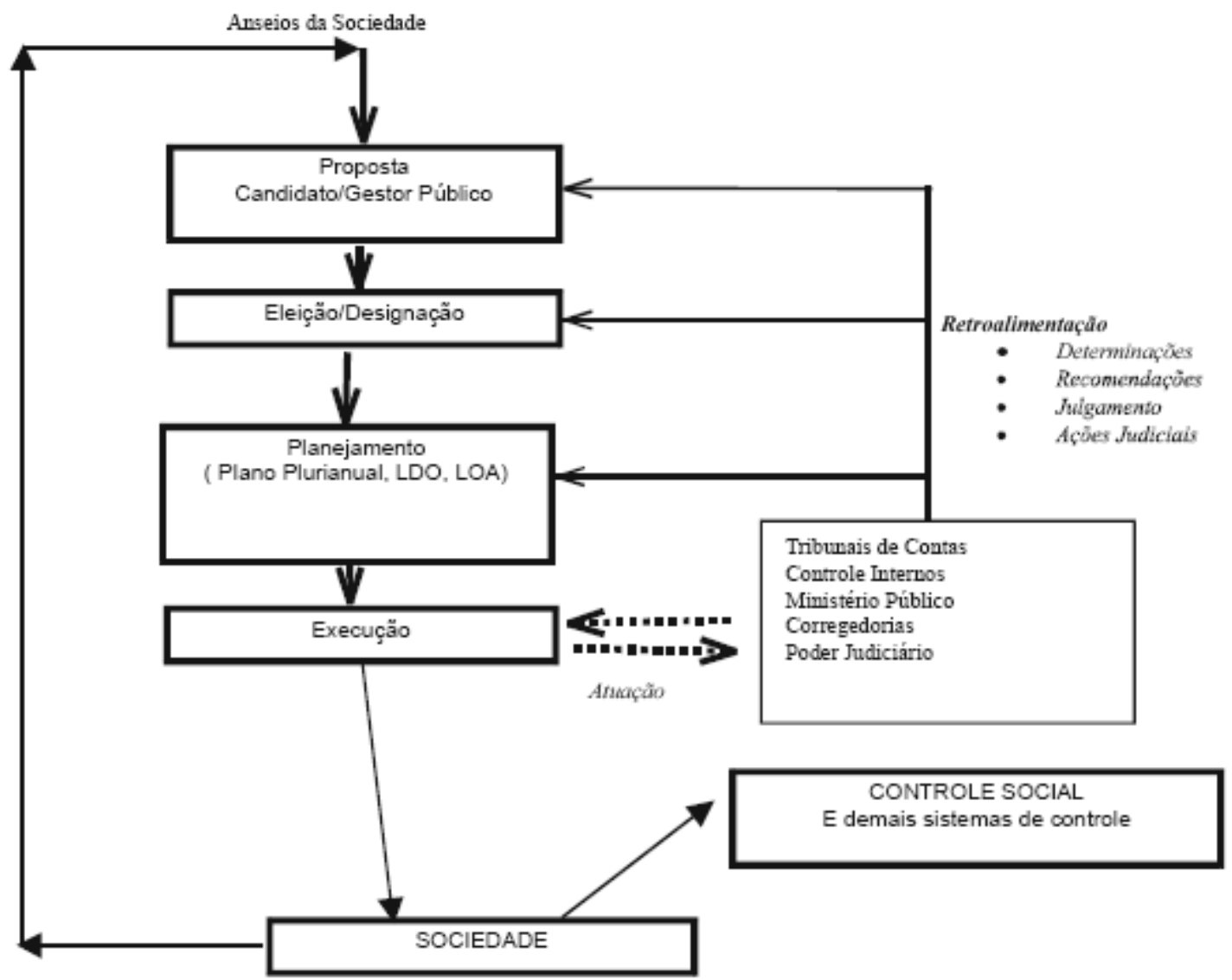

Figura 1 - Esquema de controle social na Administração Pública Fonte: Silva (2001, p. 28).

Segundo Silva (2001), atuando através do controle social e alimentando o sistema com seus anseios, a sociedade conseguiria identificar as impropriedades e as melhorias, e eliminá-las ou incentivá-las conforme suas necessidades. No entanto, segundo o autor, a análise das orientações do modelo gerencial para a realização de controles da Administração Pública deixa claro que uma série de pressuposições foram assumidas como compatíveis com a realidade do Brasil, mas não o são.

No caso do controle social, foco deste estudo, uma realidade que está muito presente é o despreparo do cidadão para atuar como controlador do gasto público.

Campos (1990 apud SILVA, 2001, p. 53), diz que no Brasil é difícil falar em controle social, pois a sociedade não está amadurecida. Existem poucas organizações por meio das quais a opinião dos cidadãos se faça ouvir, ou mesmo onde suas necessidades sejam discutidas, consolidadas e finalmente transformadas em demandas para órgãos públicos. Para Silva (2001) em países politicamente 
menos desenvolvidos, como o Brasil, o exercício da democracia é representado simplesmente pela participação em eleições esporádicas.

Essa falta de envolvimento político da sociedade civil abre espaço para que ocorram inúmeros casos de desvio ou má utilização de recursos públicos. Além disso, a falta de controle social dos atos da Administração Pública não gera informações suficientes para orientar ajustes necessários nas políticas públicas para uma aplicação mais eficiente e transparente dos recursos públicos.

Abramo (2001), em seu estudo sobre acesso à informação, apresentado no Fórum Nacional sobre Responsabilidade e Transparência no Setor Público, afirma que o acesso à informação gerada ou detida pelo setor público é uma das dificuldades para ampliar a transparência do Estado e responsabilizar os detentores de cargos públicos. Na opinião do autor, a ausência de meios organizados para proporcionar informação é, em muitos casos, fruto da falta de ação que por vezes pode ser motivada para proteger do escrutínio público a incompetência e corrupção sistemática.

Apesar da realidade descrita, de acordo com Silva (2001), existem evidências de que a corrupção, que é um fenômeno social tido como natural, atingiu níveis que a sociedade não mais tolera, e por isso é necessária uma reavaliação das formas de controle da Administração Pública.

\subsubsection{FORTALECIMENTO DO CONTROLE SOCIAL COMO RESPOSTA ÀS DIFICULDADES DA REFORMA IMPLANTADA}

De acordo com Silva (2001) o Plano da Reforma Administrativa Brasileira privilegiou aspectos relacionados com a desburocratização, a flexibilização e a redução de custos, deixando de lado outras prerrogativas como o caso das Organizações Sociais, terceiro setor, e as Agências Executivas. O problema causado por essa realidade é que, na prática, desburocratização, flexibilização e redução de custos sem o aumento de controle efetivo pode criar oportunidade para o aumento da corrupção à longo prazo. 
Para contornar esse problema, Silva (2001) sugere a valorização do controle social. Para colocar esse propósito em prática, o autor sugere: realização de discussões sobre a legislação referente a controle no Brasil, a elaboração de um projeto de educação em massa da população para que essa participe do controle da Administração Pública, a criação de canais de participação individuais combinados com um processo de informação mediante informatização, transparência e estímulo a participação do cidadão.

Em 2001, no Fórum Nacional sobre Responsabilidade e Transparência no Setor Público, Bertók, Caddy e Ruffner (2001) apresentaram o trabalho denominado "Fazendo Acontecer: Diretrizes de políticas voltadas à Responsabilização e à Transparência".

Nesse trabalho os autores (Bertók, Caddy e Ruffner, 2001,p.72) concordam com Silva (2001) e definem como obstáculos ao fortalecimento dos mecanismos de escrutínio e o acesso à informação: falta de consciência e educação por parte dos cidadãos, cultura de sigilo no âmbito da Administração Pública, falta de recursos, ausência de habilidades específicas no setor público, falta de mídia independente, barreiras tecnológicas, culturais e de conhecimento.

Outras observações apontadas por Bertók, Caddy e Ruffner (2001) referem-se ao fato de que para assegurar a informação e a participação pública é necessário, entre outros, mais responsabilização, introdução de mecanismos de monitoramento independente, promoção de cultura pró-ativa no serviço público, desenvolvimento de indicadores de desempenho, fortalecimento da capacidade das organizações da sociedade civil.

Matias-Pereira (2008) vê o controle como um instrumento da democracia. De acordo com o autor, essa afirmação se justifica da seguinte forma:

\footnotetext{
A existência de uma estrutura formal para o controle das finanças públicas, eficiente, eficaz e efetiva, para alcance do objetivo de garantir o bom desempenho das atividades estatais realizadas no interesse do bem público é um fato comum em um Estado democrático organizado (MATIASPEREIRA, 2008, p. 180).
}

Abramo (2001), afirma que uma boa quantidade de iniciativas tem acontecido no plano federal com o objetivo de gerar transparência dos atos públicos. $O$ autor cita como exemplo a implantação do ComprasNet, sistema de aquisição do Governo Federal e o SICONV que controlará as transferências voluntárias federais. 
Modesto (1997) afirma que as formas de cooperação privada e parcerias com o Poder Público, entre elas as parcerias com o terceiro setor, tem importância crescente na sociedade e estão vinculadas a idéia de participação popular na esfera pública. No entanto, o autor destaca que a falta de legislação adequada para diferenciar entidades do terceiro setor e a debilidade dos sistemas de controle tem estimulado abusos e fomentado a desconfiança em atividades e relações de parceria, que fundamentalmente necessitam desses valores.

Outro ponto que justifica o investimento no controle social, destacado por Bertók, Caddy e Ruffner (2001) é o fato de que há ligação direta entre o desenvolvimento econômico e o governo aberto, mencionando a transparência como um dos fatores principais para atrair investimento direto estrangeiro para países.

\subsection{SISTEMAS DE INFORMAÇÃO E CONTROLE SOCIAL}

Segundo Silva (2001), no Brasil o sentido de controle muitas vezes é confundido com a burocratização negativa, ou seja, o aparelho burocrático dificultando os processos administrativos. No entanto, para esse autor, um exemplo de que controle e burocratização são diferentes é a implantação de sistemas de informatização, pois esses dispositivos ampliam o controle, tornando o resultado da administração mais eficiente e ao mesmo tempo viabilizam processos mais ágeis.

Silva (2001) acredita que a informação seja um elemento básico para o controle social e pelo volume de dados nos processos governamentais o acompanhamento dessas informações só pode ser conseguido através de sistemas informatizados.

Ribeiro, Sophia e Grigório (2006) também acreditam que a informação seja a chave para um desenvolvimento político que fortaleça práticas de planejamento e avaliação participativa. Além disso, as autoras afirmam que a literatura sobre gestão social vem valorizando a democratização da informação, e que a associação entre conhecimento (informação) e tecnologia é fundamental para: 
i)produção de evidências para construção e avaliação social de políticas públicas; ii) fortalecimento das relações entre sociedade civil e Poder Público para a expansão da participação política nas decisões de interesse público/coletivo; e iii) no desenvolvimento de inovações voltadas para a eficiência da gestão governamental e transparência do setor público. (RIBEIRO, SOPHIA E GRIGÓRIO, 2006, p.624).

Pereira-Matias (2008) conclui que após a reforma de 1995 foi retomada a iniciativa do governo em tornar transparentes para a sociedade informações sobre os atos do governo. Nesse sentido foram tomadas ações de estruturação de mecanismos de controle e informação, entre eles o Sistema Integrado de Administração Financeira - SIAFI. Para o autor, a administração de dados com a utilização de recursos tecnológicos, inclusive a internet, é um fator de transparência governamental.

Ribeiro, Sophia e Grigório (2006), também verificaram que tem se multiplicado as iniciativas de governo eletrônico (soluções mediadas pelas tecnologias da informação), com vistas a criar novas formas de acesso público da sociedade à informações, intervenções e decisões governamentais. No entanto, em seu estudo, as autoras reconhecem que a consolidação dessas medidas, no âmbito da administração pública tradicional, encontra dificuldades.

Segundo Ribeiro, Sophia e Grigório (2006), a maioria dessas dificuldades estão vinculadas às exigências de perfil profissional adequado a nova realidade, às resistências culturais e barreiras socioeconômicas. Outro aspecto ressaltado pelas autoras é que disponibilizar informações e tecnologia não é suficiente para produzir transformações sociais capazes de gerar mudanças políticas. A informação tem que ser usada e para isso deve fazer sentido para diferentes atores sociais.

Silva (2001) aponta que a sociedade despreparada não se comprometerá com o controle. O autor sugere um projeto de longo prazo de educação da sociedade com introdução da matéria no currículo dos alunos de $1^{\circ} \mathrm{e} 2^{\circ} \mathrm{grau}$.

Outro ponto de melhoria quanto aos sistemas de informação do governo está relacionado a forma de tratar as informações. Silva (2001) diz que a padronização da informação nos sistemas informatizados torna-se arma poderosa no acompanhamento dos resultados do governo. Esse autor propõe a criação de um sistema comum de controle para todos os órgãos de controle. Segundo ele isso reduziria a superposição de tarefas e dispersão de dados, situações que causam apatia e desconfiança por parte da sociedade. 
Para Silva (2001) a uniformização e integração dos sistemas de informação de controle são essenciais para se melhorar a participação social na formulação das políticas públicas brasileiras.

Pereira-Matias (2008) também aponta que, apesar dos avanços, ainda não se encontram devidamente integrados os sistemas de informação do governo, não permitindo que os cidadãos visualizem com clareza todas as ações governamentais.

Apesar das restrições descritas, todos os autores citados acreditam que as novas tecnologias têm grande potencial para estabelecer novos canais de veiculação de informação, conhecimento e análises. 


\section{METODO DE PESQUISA}

Neste capitulo foram apresentados o método e as técnicas de pesquisa que foram adotados na investigação do tema deste trabalho.

\subsection{TIPO DE PESQUISA}

Neste trabalho foi utilizada pesquisa qualitativa, de natureza descritiva com foco em identificar os impactos operacionais que a implantação do SICONV trouxe na participação das entidades privadas sem fins lucrativos nas políticas públicas brasileiras.

A pesquisa bibliográfica tratou sobre o modelo de gestão pública brasileira e a participação das organizações sociais nesse contexto. Através de pesquisa bibliográfica também foi abordada a necessidade da transparência e do controle social dos atos públicos do Governo Federal.

A pesquisa documental buscou descrever o processo de transferência voluntária proposto na nova legislação, identificando e avaliando os impactos operacionais da implantação e obrigatoriedade do uso do SICONV para entidades privadas sem fins lucrativos e a preocupação do Estado em gerar transparência e controle das transferências voluntárias.

Com uso dessa metodologia e técnicas pretendeu-se responder o problema da pesquisa. 


\subsection{AMOSTRA DA PESQUISA E COLETA DE DADOS}

Os documentos necessários para a coleta de evidências foram obtidos em sítios e sistemas oficiais do governo que abordam assuntos correlatos ao pesquisado.

Foi realizada a análise documental para o levantamento dos dados. Para Lüdke e André (2005) para realizar a análise documental a primeira decisão é quanto à caracterização do tipo de documento a ser utilizado, e nessa pesquisa foram utilizados documentos do tipo oficial (decretos, leis, portarias,e instruções normativas) e documentos do tipo técnicos (relatórios, acórdãos, Diário Oficial da União, entre outros). Os documentos utilizados foram:

1) A legislação referente à transferência voluntária de recursos federais, descrita no sítio oficial do Portal de Convênios:

a) Decretos

- Decreto n 6.619/2008 - Dispõe sobre as normas relativas às transferências de recursos da União mediante convênios e contratos de repasse, e dá outras providências.

- Decreto $n^{\circ}$ 6.497/2008 - Acresce dispositivos ao Decreto no 6.170, de 25 de julho de 2007, que dispõe sobre as normas relativas às transferências de recursos da União mediante convênios e contratos de repasse.

- Decreto $n^{\circ}$ 6.428/2008 - Altera o Decreto no 6.170, de 25 de julho de 2007, que dispõe sobre as normas relativas às transferências de recursos da União mediante convênios e contratos de repasse.

- Decreto n ${ }^{\circ}$ 6.329/2007 - Altera o art. 19 do Decreto no 6.170, de 25 de julho de 2007, que dispõe sobre as normas relativas às transferências de recursos da União mediante convênios e contratos de repasse.

- Decreto $n^{\circ}$ 6.170/2007 - Dispõe sobre as normas relativas às transferências de recursos da União mediante convênios e contratos de repasse, e dá outras providências.

b) Portarias

- Portaria Interministerial $n^{\circ}$ 404, de 23 de dezembro de 2008 - Altera a Portaria Interministerial $\mathrm{n}^{\circ} 127$ /MP/MF/CGU, de 29 de maio de 2008, que 
estabelece normas para as transferências de recursos da União mediante convênios e contratos de repasse.

- Portaria Interministerial $n^{\circ} 342$, de 5 de novembro de 2008 - Altera a Portaria Interministerial $n^{\circ}$ 127/MP/MF/CGU, de 29 de maio de 2008, que estabelece normas para as transferências de recursos da União mediante convênios e contratos de repasse.

- Portaria Interministerial $n^{\circ} 165$, de 20 de junho de 2008 - Dispõe sobre a Comissão Gestora do Sistema de Gestão de Convênios e Contratos de Repasse, de que trata o $\S 1^{\circ}$, do art. 13 , do Decreto $n^{\circ} 6.170$, de 25 de julho de 2007, e dá outras providências.

- Portaria Interministerial $n^{\circ} 127$, de 29 de maio de 2008 - Estabelece normas para execução do disposto no Decreto no 6.170, de 25 de julho de 2007, que dispõe sobre as normas relativas às transferências de recursos da União mediante convênios e contratos de repasse, e dá outras providências.

- Portaria Interministerial MP/MF/MCT No24, de 19 de fevereiro de 2008 Disciplina os procedimentos operacionais para o atendimento ao disposto no art. 17 do Decreto $n^{\circ} 6.170$, de 25 de julho de 2007, e dá outras providências.

c) Instrução Normativa:

- Instrução Normativa STN no 1 de 15 de janeiro de 1997 - Disciplina a celebração de convênios de natureza financeira que tenha por objeto a execução de projetos ou realização de eventos e dá outras providências;

2) Manuais e relatórios referentes ao SICONV disponíveis no sítio oficial do Portal de Convênios;

3) Repositório que contempla a documentação do SICONV e sítio corporativo do SERPRO - Serviço de Processamento de Dados do Governo Federal;

A pesquisa documental foi realizada e registrada pela pesquisadora.

\subsection{ANÁLISE DOS DADOS}

Para a análise das informações coletadas foi utilizada a técnica denominada, por Bauer (2005), de Análise de Conteúdo (AC). 
Essa técnica é realizada através da categorização do conteúdo. Nesse estudo a categorização utilizada foi definida através do critério semântico, ou seja, categorias temáticas.

As categorias foram criadas a priori, o que segundo Puglisi e Franco (2003) significa dizer que as categorias e seus indicadores são predeterminados em função da busca a uma resposta específica do investigador.

Para Bauer (2005), a AC é uma forma de interpretar o texto tendo o referencial de codificação como direcionador. Para o autor a AC é um método de análise de texto desenvolvido dentro das ciências sociais empíricas. Bauer complementa dizendo que:

A análise de texto faz uma ponte entre o formalismo estatístico e a análise qualitativa dos materiais. No divisor quantidade/qualidade das ciências sociais, a análise de conteúdo é uma técnica híbrida que pode medir esta improdutiva discussão sobre virtudes e métodos (BAUER, 2005, p.190).

Bauer (2005) enfatiza que pesquisadores sociais tendem a subestimar materiais textuais como dados, mas que a aceitação destes como fonte valida vem sendo fortalecida como método de pesquisa. Para o autor grande parte das pesquisas sociais se baseia em entrevistas, no entanto da mesma maneira que as pessoas se expressam falando elas o fazem escrevendo. Segundo Bauer (2005), a amostra a ser utilizada no estudo depende sempre do problema de pesquisa.

Segundo Yin (2005), todas as fontes de evidências possuem pontos fortes e pontos fracos. Para o autor a fonte de evidências do tipo documentação possui os seguintes pontos fortes e os pontos fracos:

\begin{tabular}{|l|l|l|}
\hline Fonte de Evidências & \multicolumn{1}{|c|}{ Pontos Fortes } & \multicolumn{1}{|c|}{ Pontos Fracos } \\
\hline & - estável: pode ser revisada inúmeras & - capacidade de recuperação: pode \\
ser baixa.
\end{tabular}

Quadro 2 - Fonte de evidências: pontos fortes e pontos fracos

Fonte: Adaptado de Yin (2005, p. 113). 
Após a categorização foram construídos indicadores e suas análises foram o caminho para a conclusão do trabalho.

De acordo com os conceitos de Bauer (2005) e Yin (2005) e considerando o objetivo deste trabalho, considerou-se suficiente a análise documental como fonte de evidências para o estudo.

Para descrever o processo de transferência voluntária proposto na nova legislação, identificando e avaliando os impactos operacionais da implantação e obrigatoriedade do uso do SICONV para entidades privadas sem fins lucrativos, foi focalizado a parte do processo referente a proponentes, que após firmado convênio se tornarão convenentes.

Com vistas a atender ao propósito de medir a preocupação do Estado em gerar transparência e proporcionar controle sobre as transferências voluntárias - TV foram utilizadas as categorias definidas abaixo:

Categoria

Definição

1. Transparência

possibilidade de acesso do cidadẫo à informaçẫo governamental

Quadro 3 - Categorização da Transparência

Fonte: Adaptado de Matias-Pereira (2008)

Categoria

Definição

1. Controle por órgão

classificaçẫo relacionada ao órgẫo que realiza o controle, se um órgẫo interno ou nẫo a estrutura do ente controlado.

1.1 Interno

Se o controle é exercido por cada poder sobre seus próprios atos e agentes, o controle é interno.

1.2 Externo

Se o controle é exercido de um poder sobre o outro, ou mesmo da administração direta sobre a indireta é o controle externo

2. Controle com relação ao momento

2.1 Prévio controle exercido antes do ato produzir efeito

2.2 Concomitante ocorre durante a execuçẫo do ato, é o acompanhamento da açẫo.

2.3 Posterior

O controle posterior visa analisar, confirmar, corrigir ou desfazer um ato.

Quadro 4 - Categorização de Controle

Fonte: Adaptado de Silva (2001)

Quanto a categoria de controle, destaca-se duas premissas. A primeira se refere ao fato de não ter sido utilizada uma categoria denominada de Controle 
Social. Isso se deu em virtude da definição de Controle Social, que segundo Silva (2001) e o Portal da Transparência (CGU, 2009) é a possibilidade da atuação da sociedade civil por meio de qualquer uma das vias de participação democrática no controle das ações do Estado e dos gestores públicos, acompanhando, verificando e avaliando os objetivos, processos e resultados das políticas públicas, impossibilitando sua verificação na legislação. Dessa forma, a pesquisa se pautou em identificar na legislação sobre TV a preocupação do Estado em gerar transparência à sociedade. A segunda premissa foi a de considerar como controle interno o realizado não só aquele realizado por cada poder sobre seus próprios atos, mas também o realizado por agentes que sejam partes integrantes do convênio, como por exemplo, concedentes e convenentes. 


\section{APRESENTAÇÃO E ANÁLISES}

Nesta seção foi descrito e analisado o processo de transferência voluntária proposto na nova legislação, identificando os principais impactos operacionais gerados com a implantação do SICONV, na relação entre Estado e entidades privadas sem fins lucrativos.

Também foram apresentados e analisados os resultados da categorização, que permitiram identificar a preocupação do Estado em gerar transparência e controle das transferências voluntárias e as características do SICONV frente a esses conceitos.

\subsection{O PROCESSO DE TRANSFERÊNCIA VOLUNTÁRIA E O SICONV}

Para a Secretaria do Tesouro Nacional, transferência voluntária - TV é definida da seguinte forma:

são os recursos financeiros repassados pela União aos Estados, Distrito Federal e Municípios em decorrência da celebração de convênios, acordos, ajustes ou outros instrumentos similares cuja finalidade é a realização de obras e/ou serviços de interesse comum e coincidente às três esferas do Governo. (BRASIL, 2009g)

A Lei de Responsabilidade Fiscal, lei no 101/2000, no artigo número 25, define transferência voluntária como "a entrega de recursos correntes ou de capital a outro ente da Federação, a título de cooperação, auxílio ou assistência financeira, que não decorra de determinação constitucional, legal ou os destinados ao Sistema Único de Saúde".

Conforme descrito acima, e também segundo o Tribunal de Contas da União TCU (BRASIL, 2008i), as TV, em geral, são realizadas por meio de convênios e contratos de repasse, mas outros instrumentos podem ser utilizados, como o que 
ocorre com as entidades privadas qualificadas como Organizações da Sociedade Civil de Interesse Público - Oscip, que firmam termos de parceria com o Estado.

Convênio, segundo Sá e Rabello (1987, p.150), é uma palavra originária do latim (cum + veniere), e significa "uma ação conjunta de aproximação, quase sinônimo, de acordo - que sugere mais a idéia de superação de um conflito ou preocupação de preveni-lo -, e visa a construir as bases de uma colaboração mútua". Para o TCU (BRASIL, 2008i), um convênio é um acordo, ajuste ou qualquer outro instrumento que discipline a TV com o objetivo de execução de programa de governo, em regime de mútua cooperação que como partícipes tenha de um lado órgão da administração pública federal direta, autarquias, fundações pública, empresas públicas ou sociedade de economia mista, e de outro, órgão ou entidade da administração pública estadual, distrital ou municipal, direta ou indireta, ou ainda, entidade privadas sem fins lucrativos. Já o contrato de repasse se define como um instrumento para a TV por intermédio de instituição ou agente financeiro público federal, que atua como mandatário da União.

Nesse estudo foi utilizado o termo convênio para designar as modalidades de convênio e contrato de repasse.

Segundo o TCU (BRASIL, 2008i) os partícipes de um convênio são:

\begin{abstract}
Concedente: Órgão da administração pública federal direta ou entidade da administração pública indireta, responsável pela transferência dos recursos financeiros ou pela descentralização dos créditos orçamentários destinados à execução do objeto do convênio. (BRASIL, 2008i, p.15).
\end{abstract}

Convenente: Órgão da administração pública federal direta ou entidade da administração pública indireta de qualquer esfera de governo, bem como entidade privada sem fins lucrativos, com o qual a administração federal pactua a execução de programa, projeto, atividade ou evento mediante convênio (BRASIL, 2008i, p.16).

A fim de consolidar uma base de informação mais clara para todos os envolvidos no processo de transferência voluntária, a União compreendeu que era o momento de organizar um Sistema de Gestão de Convênios e Contratos de Repasse - SICONV.

A necessidade da implantação de um sistema como o SICONV foi ressaltada pelo TCU em 2006 em seus acórdãos de número 788 e 2066. No acórdão 788/2006 (BRASIL, 2006a) o TCU recomendou ao Ministério do Planejamento, Orçamento e 
Gestão - MPOG que avaliasse a possibilidade de criação ou modificação de sistema de informática de modo a permitir o acompanhamento "on-line" pelo menos em parte dos convênios, contratos de repasse ou outros instrumentos congêneres, compreendendo a sinalização automática daqueles que mostrem comportamento discrepante. Através da publicação do acórdão 2066/2006 (BRASIL, 2006b), o TCU determinou ao MPOG a apresentação de um estudo técnico com objetivo de implementar um sistema a ser disponível na "web" que permitisse o acompanhamento on-line de todos os convênios utilizados para transferir recursos públicos.

A partir das determinações e recomendações do TCU foram editadas as normas que instituíram a construção do SICONV. O Decreto 6.170/2007 (com dispositivos alterados pelos Decretos 6.329/2007 e 6.428/2008, e acrescidos pelo Decreto 6.497/2008) e a Portaria Interministerial 127, de maio de 2008, dos Ministérios do Planejamento, Orçamento e Gestão, da Fazenda e do Controle e da Transparência, com aplicação supletiva da IN/STN 01/97, naquilo que não for incompatível com os dispositivos do Decreto 6.170/2007.

O Decreto 6.170/2007 instituiu o SICONV e dispõe sobre as normas relativas às TV mediante convênios e contratos de repasse. O decreto define que o sistema deve ser aberto ao público via Internet e disponibilizado em página da web denominada Portal de Convênios.

A Portaria Interministerial 127/2008 estabelece normas para a execução do disposto no Decreto 6.170/2007. É objetivo dessa portaria tratar do credenciamento, da proposição, do cadastramento da proposta de trabalho, da contrapartida, do plano de trabalho e do projeto básico, além da execução dos convênios e da padronização de objetos detalhando todas as suas regras.

Segundo o TCU (BRASIL, 2008i), o SICONV é um sistema do Governo Federal no qual serão registrados todos os atos relativos ao processo de operacionalização das TV de recursos por meio de convênios. Para esse órgão, o objetivo do sistema é controlar o processo e dar maior agilidade, com menores custos, aos procedimentos necessários às transferências de recursos federais para estados, municípios e entidades privadas sem fins lucrativos. Em sua publicação oficial sobre as TV, o TCU afirma que a União: 
espera garantir maior transparência aos atos de gestão, pois o Portal possibilitará o acompanhamento pela sociedade de todo o processo, desde a apresentação da proposta pelo interessado até a análise, celebração e liberação de recursos pelo concedente, bem como a prestação de contas on-line da execução física e financeira, pelo convenente. (BRASIL, 2008i, p.18).

Em linhas gerais, além de proporcionar controle e transparência, o sistema buscou facilitar o acesso dos usuários aos programas oferecidos pela União.

O sistema foi desenvolvido pela Universidade Federal do Rio de Janeiro UFRJ, mas a necessidade do sistema se relacionar com outros sistemas estruturais do Governo Federal fez com que a gestão do mesmo fosse confiada ao SERPRO Serviço Federal de Processamento de Dados. O SERPRO é uma empresa pública vinculada ao Ministério da Fazenda, criada com o objetivo de modernizar e dar agilidade a setores estratégicos da Administração Pública brasileira. A Empresa, cujo negócio é a prestação de serviços em Tecnologia da Informação e Comunicações para o Governo Federal, é considerada uma das maiores organizações do setor na América Latina.

O fluxo de TV proposto pelo SICONV está representado nas figuras 2,3 e 4 . A figura 2 apresenta o Fluxo Operacional proposto pelo sistema. As figuras 3 e 4 trazem uma breve descrição das atividades dos concedentes e dos convenentes.

Para identificar as alterações operacionais ocorridas no processo de TV com foco na relação Estado e entidades privadas sem fins lucrativos, serão detalhadas as atividades dos convenentes, papel assumido pelas entidades privadas sem fins lucrativos, ressaltando o tratamento dado a esse tipo de entidade.

A legislação utilizada para o detalhamento das atividades foi a Portaria Interministerial $n^{\circ} 127 / 2008$ e os manuais disponíveis no Portal de Convênios:

\section{Fluxo operacional}

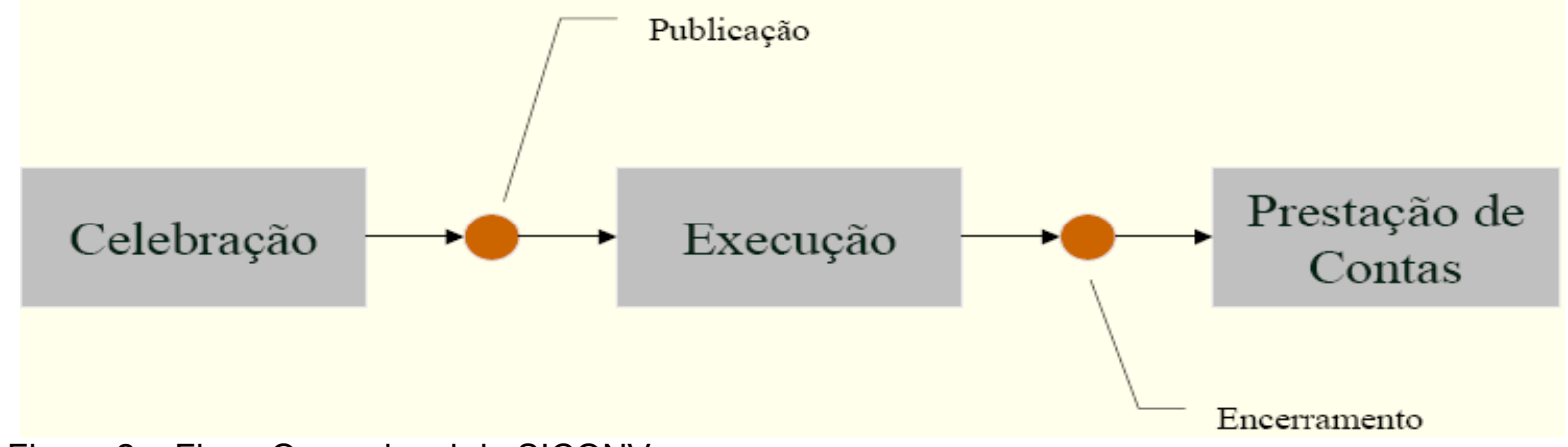

Figura 2 - Fluxo Operacional do SICONV.

Fonte: Adaptado BRASIL (2009e). 


\section{Módulos da Celebração}

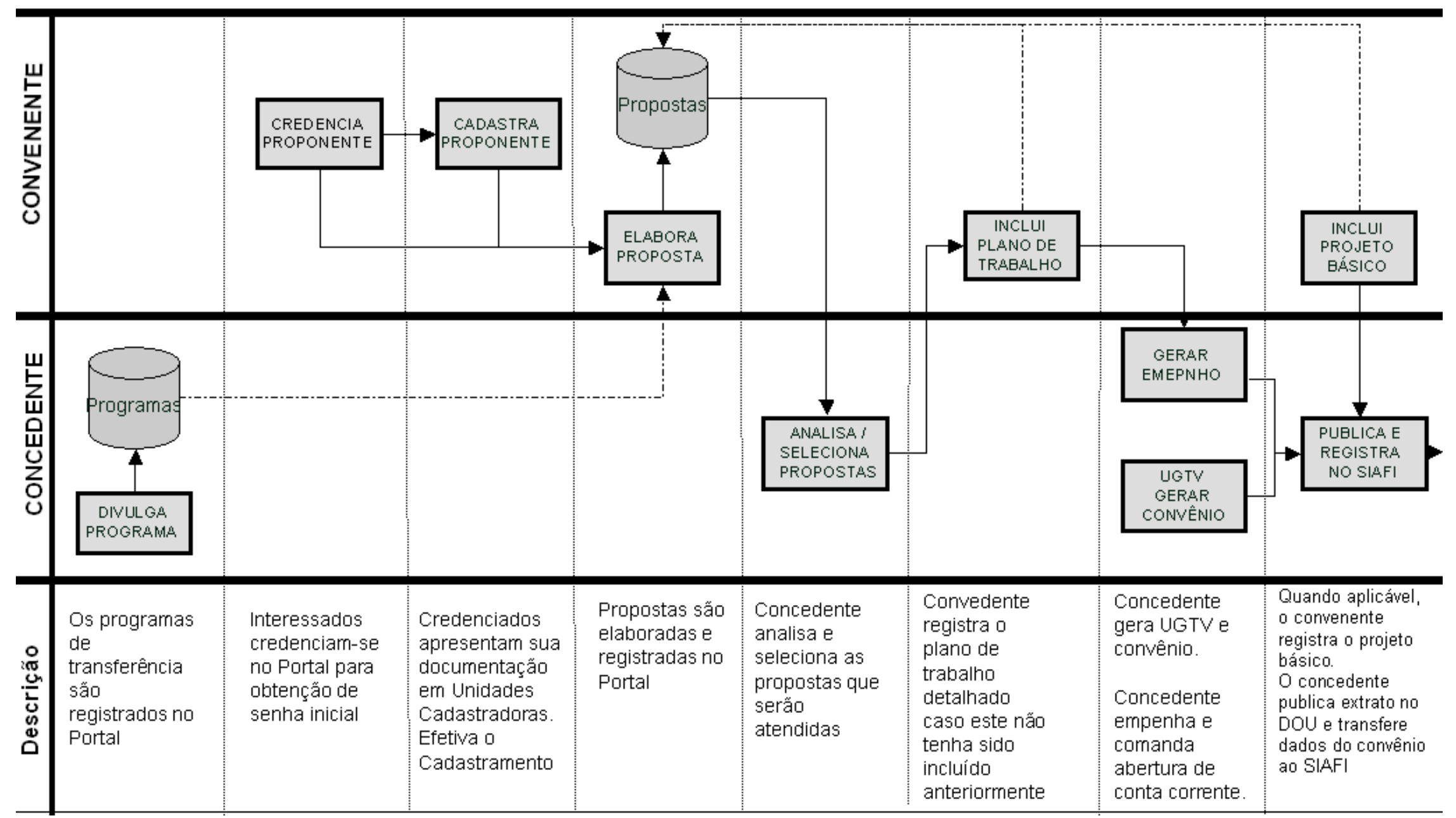

Figura 3 - Fluxo Operacional do SICONV - Módulo de Celebração de Convênio

Fonte: Adaptado BRASIL (2009e). 


\subsubsection{DETALHAMENTO DAS ATIVIDADES, EXECUTADAS PELO CONVENENTE, REFERENTES AO PROCEDIMENTO DE CELEBRAÇÃO DE CONVÊNIOS}

\section{1) Credenciar}

O credenciamento é ato simplificado pelo qual o convenente ingressará no Sistema de Gestão de Convênios e Contratos de Repasse - SICONV e passará a ter sua identificação própria. Trata-se de condição básica para atuar junto ao portal de convênios, inclusive para a apresentação de proposta.

Para concluir esta etapa, não será necessário enviar original ou cópia de qualquer documentação, basta informá-los no Portal de convênios.

Para o credenciamento serão informados os dados cadastrais do responsável pelo credenciamento e posteriormente os dados da entidade. Concluído o credenciamento o responsável pelo credenciamento receberá, através de e-mail automático enviado pelo sistema, login e senha para o primeiro acesso ao SICONV.

Estando credenciado o convenente poderá manifestar interesse em celebrar convênios enviando propostas para programas disponibilizados que aceitam propostas de proponentes não cadastrados.

2) Cadastrar

O cadastramento possui caráter complementar ao credenciamento. Essa etapa exige a presença física de um representante da entidade em uma das Unidades Cadastradoras do SICAF, essa foi uma estratégia adotada com a expectativa de diminuir os custos com deslocamento físico.

A entidade privada sem fins lucrativos apresentarão documentos referentes à sua qualificação jurídica, fiscal e previdenciária, bem como a sua capacidade técnica e operacional. Vale ressaltar que essas entidades devem apresentar documentação diferente da exigida dos entes da federação. As declarações deverão se digitalizadas e salvas em arquivo com extensões definidas no SICONV.

$\mathrm{O}$ cadastramento será realizado uma única vez, e terá validade de um ano. $\mathrm{O}$ cadastramento terá efeito junto a todos os órgãos repassadores de recursos da 
União.Com o cadastramento efetivado o representante legal da entidade receberá senha específica para a cessar o SICONV e conceder senhas para os servidores da entidade operarem o sistema de acordo com o perfil de acesso definido.

3) Incluir Elaborar Proposta

A proposta de trabalho é uma peça preparatória do Plano de Trabalho, podese afirmar que é uma versão simplificada desse, mas deve conter um conteúdo mínimo composto por: descrição de objeto; justificativa com a caracterização dos interesses recíprocos, a relação entre a proposta e o programa federal e o público alvo; estimativa de recurso financeiro, discriminando o valor a ser realizado pelo concedente e a contrapartida prevista para o proponente; previsão de prazo para execução; informações relativas à capacidade técnica e gerencial do proponente para execução do objeto.

No caso de aceitação da proposta o proponente deverá atender as exigências para efetivação do cadastro, se já não o tiver realizado, e incluirá o Plano de Trabalho no SICONV.

A entidade deverá informar na proposta a agência e o banco no qual deseja que seja aberta a conta específica para o convênio.

4) Incluir Plano de Trabalho

O plano de trabalho é a peça elaborada antes do convênio e tem a missão de definir uma série de questões relacionadas ao acordo, especialmente quanto aos aspectos de execução operacional e financeira. Sua elaboração é imprescindível, tornando nulo o convênio celebrado sem a apresentação deste.

O conteúdo mínimo para essa peça é composto por: justificativa para celebração do instrumento; descrição completa do objeto a ser executado; descrição das metas a serem atingidas; definição das etapas ou fases de execução; cronograma de execução de objeto; cronograma de desembolso e plano de aplicação de recursos a serem desembolsados pelo concedente e da contrapartida financeira do proponente. Vale ressaltar que, sendo necessário, é possível atualizar essa peça no decorrer do convênio. 
5) Incluir Projeto Básico e Termo de Referência

São peças exigidas conforma o objeto do convênio. Será necessária a elaboração de projeto básico à convênios que constem obras e serviços de engenharia. É uma peça de engenharia e consiste na descrição de uma obra, definindo cronologicamente suas etapas e fases e vários detalhes técnicos acerca da forma de execução.

O termo de referência é utilizado quando o objeto do convênio envolve aquisição de bens ou prestação de serviços. Deverá conter elementos capazes de propiciar a avaliação de custos pela Administração, diante de orçamento detalhado, considerando preços de mercado, a definição dos métodos e prazo de execução do objeto.

A apresentação do Projeto Básico ou do Termo de Referência se dá após a assinatura do convênio e antes da liberação da primeira parcela, no entanto, o concedente poderá exigi-lo juntamente com o Plano de Trabalho. 
Módulos da Execução e da Prestação de Contas

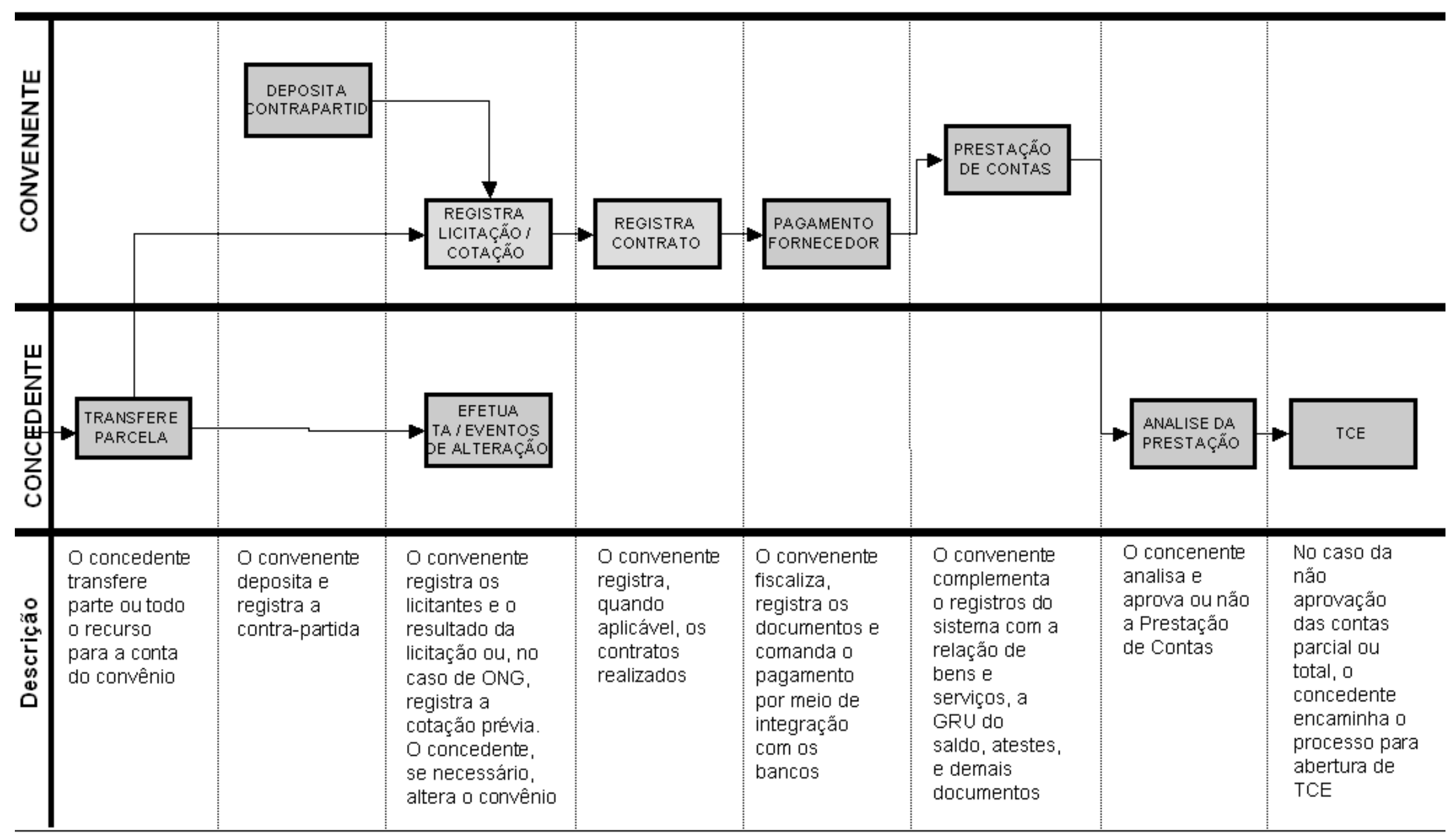

Figura 4 - Fluxo Operacional do SICONV - Módulo de Execução e Prestação de Contas de Convênio Fonte: Adaptado BRASIL (2009e). 


\subsubsection{DETALHAMENTO DAS ATIVIDADES, EXECUTADAS PELO CONVENENTE, REFERENTES AOS PROCEDIMENTOS DE EXECUÇÃO E PRESTAÇÃO DE CONTAS DE CONVÊNIOS}

\section{1) Registrar Contra Partida}

Após a publicação do convênio, a entidade deverá dirigir-se ao banco e agência indicados para a regularização da conta convênio, gerada automaticamente pelo concedente e específica para o convênio.

Quando houver contrapartida, a entidade deverá realizar o depósito da mesma e registrar no Portal dos convênios. Após a confirmação do banco da regularização da conta e depósito da contra-partida a entidade poderá iniciar a execução.

2) Registrar Licitação e Resultado, Empenhar, Registrar Contratos, Registrar NF e Liquidar

A contratação de terceiros por entidades privadas sem fins lucrativos com recursos da Administração Pública Federal é diferenciada da realizada por órgão e entidades da própria Administração.

As entidades administrativas devem utilizar-se da licitação, que é regra para a Administração Pública. As entidades privadas sem fins lucrativos deverão realizar, no mínimo, cotação prévia de preços no mercado, observando os princípios da impessoalidade, moralidade e economicidade.

A cotação prévia se dará com a publicação da descrição completa e detalhada do objeto a ser contratado no SICONV. A seleção da proposta mais vantajosa deverá ser fundamentada segundo critérios definidos no chamamento público para a cotação prévia e seu resultado deverá ser registrado no SICONV.

Quando não se apresentarem interessados na cotação prévia, será realizada pesquisa prévia de preço no mercado, também por intermédio do SICONV.

Os registros dos contratos celebrados pelo beneficiário na execução do objeto é condição indispensável para sua eficácia e para a liberação das parcelas subseqüentes do convênio. 
Todo o processo de compras e contratação de bens, obras e serviços das entidades privadas sem fins lucrativos será realizado, ou registrado, no SICONV.

\section{3) Pagar Fornecedor}

A saída de quantia para realização de pagamentos da conta do convênio normalmente será feita por meio de transferência bancária, mediante crédito em conta dos fornecedores e prestadores de serviço. Excepcionalmente, permite-se pagamento em espécie, mediante saque, por decisão da autoridade máxima do concedente. Em se tratando de despesa imprevista que deva ocorrer com dinheiro, sem a possibilidade de transferência bancária, poderá ocorrer uma única vez durante a vigência do convênio para pessoa física observado o limite de $R \$ 800,00$. As duas situações demandarão informação sobre o beneficiário no SICONV.

O pagamento ao fornecedor será realizado a partir do comando do SICONV denominado Ordem Bancária de TV - OBTV, e deverá ser informada a destinação do recurso, o nome e o CNPJ ou CPF do fornecedor, o contrato a que se refere o pagamento, a meta, etapa ou fase do plano de trabalho, a comprovação do recebimento do objeto do contrato. Também deverá ser informado se o pagamento é com recurso do repasse ou da contra-partida. O pagamento depende da integração do SICONV com o banco federal da conta do convênio e com o SIAFI.

A liberação de parcelas subseqüentes do convênio está condicionada à aprovação de parcela anteriormente recebida.

\section{4) Prestar Contas}

Na prestação de contas cabe ao convenente provar a boa e regular aplicação dos recursos públicos. A prestação de contas é o momento principal, mas não único de demonstrar formalmente toda a aplicação das verbas públicas.

O SICONV possibilitará o acompanhamento, pela autoridade competente do concedente, de todo o processo a medida que se desenvolve. A alimentação do SICONV pelos bancos trará o registro pormenorizado de todas as movimentações ocorridas durante o processo.

Deve-se ressaltar que findo o prazo para prestação de contas e essa não for apresentada, o concedente registrará no SICONV a inadimplência e adotará as medidas cabíveis para o ressarcimento de danos ao erário, por meio da Tomada de Contas Especial. 


\subsubsection{ANÁLISE DAS PRINCIPAIS ALTERAÇÕES PROPOSTAS PELO DECRETO No 6.170/2007 E PELA PORTARIA INTERMINISTERIAL No 127/2008 À INSTRUÇÃO NORMATIVA NN 01/1997.}

Conforme exposto anteriormente, o processo de TV apresentava muitos problemas, desde a celebração dos convênios até sua prestação de contas. Essas questões, que se apresentavam como desafios, comprometiam a eficiência do processo. Por essa razão a Instrução Normativa 01 de 1997 foi substituída por um novo conjunto de regras, descritos no Decreto $n^{\circ} 6.170 / 2007$ e na Portaria Interministerial $n^{\circ} 127 / 2008$, que se consolidaram na implantação do SICONV. Na análise realizada foi utilizada a Portaria Interministerial $n^{\circ} 127 / 2008$, pois é nesse instrumento que são detalhadas as regras dispostas no Decreto $n^{\circ}$ 6.170/2007.

$\mathrm{Na}$ análise do novo processo podem ser considerados destaques as alterações relacionadas a consolidação da base de informações de convênios, a disponibilização dessa base em uma página da Internet, a integração dessa base com sistemas estruturados do governo e com a rede bancária, ao processo de prestação de contas, conforme segue:

1) Consolidação da base de informação

Antes da implantação do SICONV não existia uma base única de informações sobre convênios firmados pelo Governo Federal. Cada entidade adotava procedimentos que considerava mais adequados ao cumprimento das leis vigentes. Um reflexo dessa realidade é o fato de atualmente não ser possível informar quantas e quais entidades privadas sem fins lucrativos foram financiadas pelo governo e onde atuam. A base integrada de informações permitirá a realização de mais controle sobre esses recursos de governo, além de dar visibilidade de todo o processo. Tais mudanças podem ser verificadas na previsão de alguns artigos da Portaria Interministerial $n^{\circ} 127 / 2008$, conforme abaixo:

- O Art $3^{\circ}$ prevê que os atos e procedimentos relativos a convênios realizados através de TV com o Governo Federal serão realizados via SICONV. Antes da implantação do SICONV as informações sobre os convênios firmados com o 
Governo Federal estavam espalhadas em vários sistemas de governo, não sendo possível dar visibilidade do processo para órgão controladores e para a sociedade. A consolidação em uma base única de informação de todo o processo de TV, desde sua celebração a prestação de contas, o torna mais claro a todos os envolvidos e beneficiados.

- O Art $4^{\circ}$ prevê Entidades da Administração Pública, concedentes, que pretenderem executar programas, projetos e atividades que envolvam TV, deverão divulgar anualmente no SICONV a relação dos programas e critérios de seleção do convenente. Essa nova exigência garante que todos os programas que o governo deseja firmar no decorrer do exercício estejam disponíveis em um só lugar, num mesmo período. Isso facilita o controle dos convênios firmados e torna eficaz o processo de divulgação dos programas, pois as entidades parceiras buscam em uma só base de informações oportunidades de convênios com o Governo Federal.

- O Art 17 estabelece que o cadastramento será realizado uma única vez no sistema, terá validade de um ano e será realizado por Unidades Cadastradoras do SICAF. Esse novo procedimento dispensa entidades privadas sem fins lucrativos, convenentes, de se credenciarem e cadastrarem várias vezes. Antes do SICONV eram exigidos o credenciamento, o cadastramento e a apresentação da documentação a cada novo convênio, agora será exigido uma única vez. O credenciamento e cadastro em Unidades Cadastradoras do SICAF visa diminuir os custos dos convenente, uma vez que o cadastramento exige a presença física de representante do mesmo.

- Segundo o previsto nos Art 45 a 48 As entidades privadas sem fins lucrativos deverão realizar cotações prévias para a contratação de bens e serviços, e essas cotações deverão ser realizadas via SICONV. Registro de licitações, e procedimentos decorrentes desses também serão registrados no SICONV. Antes não havia controle das contratações de entidades privadas sem fins lucrativos.

- Os Art 63 a 65 definem a inscrição de inadimplência no SICONV, fator restritivo a novas TV. Antes do Siconv a inadimplência era registrada em outros sistemas, possibilitando a realização de convênios com entidades inadimplentes. 
2) Disponibilização da base de informações de convênios em uma página da Internet

A disponibilização da base de informações de convênios em uma página da internet possibilitará que todos os convênios firmados com o governo sejam acompanhados e controlados por órgãos envolvidos no processo e também pela sociedade, o que não era possível antes da implantação do SICONV. Essa nova realidade dá publicidade efetiva dos atos referentes aos convênios.

- O Art $3^{\circ}$ define o SICONV aberto à consulta pública por meio do Portal dos Convênios.A partir do SICONV, será possível verificar passo a passo o cumprimento dos termos do acordo. Todos os dados dos repasses e as justificativas dos ministérios para beneficiar uma entidade em detrimento de outra serão públicos, o que tende a reduzir práticas irregulares e evitar influências diversas no procedimento de escolha das entidades privadas sem fins lucrativos parceiras. No cadastramento e na prestação de contas deverão ser digitalizados e salvos no SICONV documentos que comprovem as informações declaradas pelos convenentes e a execução do programa (fotos de obras). Também existem formulários para apresentação on-line de projetos, planos de trabalho, relatórios, conciliação bancária, prestação de contas.

3) Integração com sistemas estruturadores do governo e com a rede bancária (RFB, SIAFI, CEF, BB, BNB, BASA etc.)

O SICONV prevê integração com os seguintes sistemas estruturadores: Sistema de Informações Gerenciais e de Planejamento - SIGPLAN, Sistema de Cadastramento de Fornecedores - SICAF, Sistema Integrado de Administração Financeira do Governo Federal - SIAFI, Sistema de Informações Organizacionais do Governo Federal - SIORG, Sistema Integrado de Administração de Serviços Gerais SIASG. Essas integrações garantem que regras exigidas desde a celebração até prestação de contas de convênios sejam cumpridas, além de dar agilidade ao processo. Como exemplo pode-se citar que apenas convenentes que comprovarem a regularidade de pagamento de impostos federais, estaduais e municipais poderão firmar convênios. 
- O Art 33 e 34 estabelecem que a publicidade dos convênios no Diário Oficial da União será assegurada pela publicação dos extratos dos convênios no Diário Oficial da União, a qual será comandada diretamente a partir do SICONV.

- O Art 42 se debruça sobre os recursos do convênio depositados e geridos em conta específica do convênio, aberta em instituições financeiras controladas pela União e com regras específicas. A abertura de conta específica do convênio será comandada via SICONV. As informações bancárias serão transferidas para o SICONV e SIAFI. Antes do SICONV não havia a exigência de uma conta específica para o convênio, e não era possível acompanhar e controlar os gastos realizados com os recursos do convênio.

- O Art 50 define que para a realização de pagamentos normalmente será realizada a transferência bancária. Excepcionalmente, mediante autorização da autoridade máxima do concedente, permite-se pagamento em espécie, inserindo posteriormente as informações no SICONV. Em se tratando despesa imprevista, fica autorizado uma vez no decorrer do convênio o pagamento de pessoa física no limite de $R \$ 800,00$. Essas medidas garantem que se conheçam os beneficiários finais de pagamentos realizados com recursos do convênio.

\section{4) Prestação de Contas}

A implantação do SICONV suprimiu a prestação de contas parcial e simplificou o rol de documentos necessários à conferência da prestação de contas, uma vez que os pagamentos e a conciliação bancária são feitos on line, o que não ocorria na situação anterior.

- Dos Art 56 a 60 pode-se destacar que o comando dos pagamentos do convenente será realizado via SICONV e sua integração diária com a rede bancária. Outro benefício do acompanhamento a medida que o contrato se desenvolve é a prevenção do acúmulo de estoque de processos com prestação de contas a serem analisadas.

Vale destacar que outras alterações implementadas pela nova legislação foram inovadoras. Como exemplo pode-se citar as vedações e novas concessões do governo frente os convenentes, que facilitam o acerto entre as partes. 
As vedações estão firmadas no art $6^{\circ}$ da Portaria Interministerial 127/2009, e se referem a não promoção de TV para órgão da Administração Pública cujo valor seja inferior a $R \$ 100.000,00$, que visa a economicidade e eficiência, pois repasses inferiores ao valor definido têm a gestão muito onerosa e a não promoção de TV com Entidade Privada sem fins Lucrativos que tenham como dirigentes, proprietários ou controladores, membros do Poder Executivo, Legislativo, Judiciário, Ministério Público e Tribunal de Contas da União, bem como respectivos cônjuges, companheiros, e parentes em linha reta, colateral ou por afinidade até o $2^{\circ} \mathrm{grau}$, que visa implementar o princípio da moralidade, pois é um critério objetivo para a escolha da entidade a ser beneficiada.

Quanto às novas concessões do governo, que facilitam e promovem mais interesse de entidades em firmar convênios com o governo, destacam-se as firmadas nos artigos 20, 23 e 39 da Portaria Interministerial 127/2009. No art 20 foi autorizada a aceitação de contrapartida em bens e serviços, o que facilita a contrapartida das entidades. No artigo 23 , foi autorizada a apresentação do projeto básico ou termo de referência após assinatura do convênio, ou seja, a primeira parcela do convênio poderá ser utilizada para a elaboração do projeto básico ou termo de referência. $\mathrm{O}$ artigo 39 permite o custeio de despesas administrativas das entidades privadas sem fins lucrativos, observando o limite de $5 \%$ do valor do convênio.

Desde $1^{\circ}$ de julho de 2008 (BRASIL, 2007b), o SICONV está disponível para os usuários, e a obrigatoriedade de utilização do referido sistema por concedentes e convenentes deu-se a partir de $1^{\circ}$ de setembro de 2008 (BRASIL, 2008b).

Apesar da obrigatoriedade da utilização do SICONV estar firmada em lei, ainda existem convênios sendo firmados e executados fora do sistema. Essa realidade se justifica em decorrência da não implantação de todos os módulos do sistema e da necessidade de ajustes nos módulos implantados.

De acordo com mensagem 2009/0428959 (BRASIL, 2009f), disponível no Portal dos Convênios, e a Estrutura Analítica de Projeto do sistema (MACHADO, 2009), disponível em repositório que contempla a documentação do SICONV, os módulos do sistema ainda não implementados se referem a integração do SICONV com outros sistemas de governo, a integração com a rede bancária, Integração com a Imprensa Nacional, e o módulo de prestação de contas. 
Um exemplo das dificuldades geradas pela não implantação dos módulos acima citados é a não integração com o SIAFI, que pode gerar perda de informações sobre os convênios, pois antes da implantação do SICONV os dados cadastrais dos convenentes, o plano de trabalho e a prestação de contas, entres outros, eram armazenados no SIAFI, no entanto após o SICONV apenas os dados contábeis passaram a ser armazenados no SIAFI.

Para atender aos usuários do SICONV, e minimizar as dificuldades de implantação, foi criada uma Central de Serviços no SERPRO para esclarecer questões referentes à operação técnica. As dúvidas relacionadas ao processo normativo, além da manutenção e evolução do sistema, são tratadas por uma equipe estruturada no MPOG.

Destaca-se que paralelo a implantação do SICONV, foi disponibilizado, no Portal de Convênios, treinamento à distância, no módulo de ensino a distância (EAD), com informações sobre como operar o sistema. Por meio dessa ferramenta é possível realizar simulações das funcionalidades, exatamente como ocorre no ambiente de produção. Além do treinamento em EAD foram realizados treinamentos presenciais que, segundo o MPOG, formaram 900 servidores federais como multiplicadores de conhecimento sobre o sistema.

Também no Portal de Convênios está disponível toda a legislação referente ao processo de TV e manuais para o convenente e concedente que tratam de forma muito clara do novo processo proposto.

Apesar das dificuldades enfrentadas na implantação do sistema, pode-se afirmar que frente a suas diretrizes e pressupostos, firmados na ênfase na transparência à sociedade, redução do custo operacional, englobar todo o ciclo das transferências, facilitar a fiscalização e controle, simplificar e agilizar procedimentos e ter interoperabilidade com demais sistemas estruturadores da Administração o SICONV apresenta-se como uma ferramenta adequada.

Deve-se considerar que um sistema da complexidade do SICONV tem um processo gradual de consolidação. Os desafios a curto prazo se referem a mudança tecnológica, desde a implantação do sistema, sua integração com outros sistema do governo e com a rede bancária, a capacitação dos usuários, mas seu maior desafio é a necessidade de mudança cultural em todas as esferas de governo e também na sociedade. 


\subsection{A PREOCUPAÇÃO DO ESTADO QUANTO A TRANSPARÊNCIA E CONTROLE E O SICONV}

Para identificar a preocupação do Estado em gerar transparência e controle das transferências voluntárias foi analisada legislação disponível no Portal de Convênios do Governo Federal. Após a análise da legislação frente a esses conceitos, foram identificadas no sistema funcionalidades e premissas que refletem essas preocupações.

Segue abaixo a legislação utilizada para verificar a preocupação do Estado com a transparência e o controle das transferências voluntárias:

1) Decretos

- Decreto $n^{\circ}$ 6.619/2008, Decreto $n^{\circ}$ 6.497/2008, Decreto $n^{\circ}$ 6.428/2008, Decreto $n^{\circ}$ 6.329/2007, Decreto $n^{\circ}$ 6.170/2007.

2) Portarias

- Portaria Interministerial $n^{0} 404$, de 23 de dezembro de 2008, Portaria Interministerial $n^{\circ} 342$, de 5 de novembro de 2008, Portaria Interministerial $n^{\circ} 165$, de 20 de junho de 2008, Portaria Interministerial $n^{\circ} 127$, de 29 de maio de 2008, Portaria Interministerial MP/MF/MCT No24, de 19 de fevereiro de 2008

3) Instrução Normativa:

- Instrução Normativa STN No 1 DE 15 de janeiro de 1997.

Analisados os resultados obtidos com a pesquisa, o que se verificou quanto a preocupação com a transparência das transferências voluntárias é que essa surgiu na legislação mais recente, a partir da publicação do decreto número 6.170 de julho de 2007 e da Portaria Interministerial 127, de 29 de maio de 2008 . Ficou claro que antes dessa publicação a preocupação do Estado era gerar controle para o próprio governo, através de controles internos ou externos.

A legislação publicada antes do decreto 6.170/2007 utilizava-se apenas da publicidade dos atos públicos no Diário Oficial para dar à sociedade acesso a informação. A publicação do decreto 6.170/2007 tornou o SICONV o instrumento oficial para celebração, liberação de recursos, acompanhamento da execução e prestação de contas dos convênios, e posteriormente a Portaria Interministerial número 127 de maio de 2008, deixa clara a mudança de postura do Estado frente a 
necessidade de gerar transparência das transferências voluntária ao cidadão, pois $26 \%$ dos artigos dessa portaria referenciam-se a necessidade de transparência, sempre apresentando o SICONV como instrumento para dar ao cidadão acesso a todas as informações do processo.

A premissa legal de que o sistema, que operacionaliza todo o processo de TV, esteja disponível na internet e que seja aberto à consulta pública reflete a preocupação do Estado em gerar transparência à sociedade desde que se iniciou a reformulação do processo de TV.

Vale destacar, que devido ao estágio inicial da implantação do sistema, atualmente encontra-se disponível para acesso da sociedade as informações referentes a divulgação de programas que o governo tem interesse em realizar através de parceria com outras entidades.

Quanto à categoria controle, o que foi verificado é que a preocupação em gerar controle sobre os convênios firmados pela Administração Pública sempre existiu, mas essa se focava em controles internos e realizados posteriormente ao ato.

A publicação do decreto 6.170/20 e da Portaria Interministerial 127/2008 fez surgir a preocupação e necessidade de se realizar controles prévios e concomitantes a execução dos atos dos convênios, sem abandonar o controle realizado posteriormente ao ato.

Destaca-se que dos 74 artigos que compõem a Portaria Interministerial $127 / 2008$, 4\% citam a necessidade de realizar o controle prévio, $15 \%$ o controle concomitante e outros $15 \%$ posterior.

Foi verificado na legislação que a preocupação com o controle interno é mais forte que a destinada ao controle externo, mas que essa foi fortalecida pela publicação do decreto $6.170 / 20$ e da Portaria Interministerial 127/2008. Isso é retratado pelo fato de a legislação exigir como cláusula obrigatória nos convênios a que dispõem sobre o acesso livre dos servidores do concedente ou órgãos de controle interno ou externo aos atos do convênio. Outro aspecto explícito se refere ao desempenho de suas funções de acompanhamento ou fiscalização dos recursos federais que prevê a atuação da Controladoria Geral da União - CGU, através de auditorias periódicas nos instrumentos celebrados pela União.

Além disso, a portaria diz que aquele que por ação ou omissão causar obstáculo a atuação de servidores do concedente ou órgãos de controle, no 
desempenho de suas funções de acompanhamento ou fiscalização dos recursos federais transferidos ficará sujeito a responsabilização administrativa, civil e penal.

No sistema, além de todos os passos do convênio serem registrados e disponibilizados, possibilitando, por exemplo, saber quantas e quais entidades privadas sem fins lucrativos financiadas pelo governo atuam no nordeste, pode-se destacar como inovações que garantem o acompanhamento e controle dos convênios os seguintes fatos: o registro das cotações prévias das entidades privadas sem fins lucrativos para a contratação de bens e serviços e o registro de licitações e procedimentos decorrentes; o registro de inadimplência; a digitalização e disponibilização de documentos que comprovem as informações declaradas pelos convenentes no cadastramento e a execução do programa (fotos de obras) na prestação de contas; a conciliação bancária e prestação de contas feitos on line, o que suprimiu a prestação de contas parcial e simplificou o rol de documentos necessários à conferência da prestação de contas.

O SICONV foi todo estruturado para atender às regras relativas ao processo de transferência voluntária disciplinadas no Decreto 6.170/2007, que também o instituiu, e na Portaria Interministerial 127/2008, que estabeleceu normas para a execução do disposto no Decreto 6.170/2007.

Analisados os procedimentos operacionais estabelecidos no sistema, a expectativa é que após a implantação completa do SICONV todos os atos relativos ao processo de operacionalização das TV por meio de convênios sejam disponíveis para o acompanhamento e controle de todos os interessados, o que será garantido pelas inovações relacionadas à consolidação da base de informações de convênios, a disponibilização dessa base em uma página da Internet, a integração dessa base com sistemas estruturados do governo e com a rede bancária e ao processo de prestação de contas tragam transparência e controle. 


\section{CONCLUSÕES}

De acordo com o pesquisado e demonstrado nesse estudo, com relação ao processo de transferências voluntárias, existe um arcabouço legal extensivo a todos os órgãos públicos e partes envolvidas no processo, estabelecendo responsabilidades e conseqüências em caso do seu não cumprimento. Além da legislação, está em fase de implantação um sistema de informação capaz de dar a condição necessária para gerar transparência e controle de todo o processo de transferência voluntária.

Apesar do acima constatado, deve-se ressaltar que para cumprir o descrito na lei e fazer com que de fato sejam implementadas a solicitações legais que garantam a transparência e o controle, especialmente o controle social, é necessário que um amplo leque de condições sejam satisfeitas. Entre essas está o treinamento de agentes públicos para a transparência e a existência de uma demanda organizada por grupos de interessados da sociedade dotados de conhecimento sobre diferentes áreas de governo.

É certo que as novas tecnologias de comunicação e informação oferecem diversas vantagens sobre os meios de comunicação tradicionais, proporcionando um ideal para a comunicação democrática. No entanto é preciso considerar que para fortalecer a democracia é necessário, além de novas estruturas de comunicação e informação, a motivação, o interesse e a disponibilidade dos cidadãos para se engajar em discussões e controles sobre assuntos relacionados a políticas públicas.

Dentro do contexto apresentado, os movimentos sociais, o terceiro setor, podem ser indicados como uma das soluções para promover a participação da sociedade no controle e deliberação de políticas públicas. Autores dedicados ao estudo dos movimentos sociais insistem que os movimentos sociais e associações voluntárias são preocupados em alcançar uma determinação ativa de seus destinos, são mais aptos que os cidadãos comuns para organizar um conhecimento próprio, fruto de uma atitude reflexiva em relação à própria motivação de agir, desenvolvendo a capacidade de examinar criticamente os próprios desejos e de interpretar a própria situação na relação com os outros atores sociais. 
Concorda-se que essa seja uma opção adequada para envolver a sociedade no controle da Administração, no entanto, essa solução não substitui a necessidade de se capacitar o cidadão comum para que esse tenha possibilidade de compreender os negócios públicos rotineiros que impactam no seu dia-a-dia. Como resposta a essa questão, considera-se adequada a descrita por Silva (2001), que sugere a elaboração de um projeto de educação em massa da população para que essa participe do controle da Administração Pública. Outro fato que fortalece a necessidade de capacitação do cidadão comum é que muitas entidades privadas sem fins lucrativos têm projetos financiados pelo Estado, são parceiras desse, o que pode influenciar na forma que essa entidade representa a sociedade.

Conclui-se que uma legislação adequada e a existência de tecnologias de informação e da comunicação facilitam e agilizam os processo de iteração entre o governo e a sociedade, contudo não determinam o procedimento da interação comunicativa e nem garante a reflexão crítico-racional da sociedade.

Por fim, sugere-se que após a consolidação do SICONV seja promovida uma avaliação da qualidade da transparência gerada pelo mesmo. Para realizar esse trabalho recomenda-se a utilização das técnicas descritas no estudo coordenado pelo Departamento de Governo Eletrônico, da Secretaria de Logística e Tecnologia da Informação, do Ministério do Planejamento, Orçamento e Gestão (BRASIL, 2009a). Essa publicação, denominada Indicadores e Métricas para Avaliação de Eserviços, trata-se de um conjunto de indicadores focados na avaliação de uma maior ou menor conveniência para o cidadão dos serviços prestados pelo governo por meios eletrônicos, considerando seu nível de maturidade, facilidade de uso, comunicabilidade, multiplicidade de acesso, disponibilidade, acessibilidade, transparência e confiabilidade.

Também após a consolidação do SICONV, parece viável e de interesse social que se realize pesquisa que retrate os impactos orçamentários e financeiros que o sistema gerou na relação Estado e terceiro setor. 


\section{REFERÊNCIAS}

ABRAMO, C. W. Acesso à informação - Um longo caminho a ser trilhado. In:FÓRUM NACIONAL SOBRE RESONSABILIDADE E TRANSPARÊNCIA NO SETOR PÚBLICO. 2001. Brasília.Anais... Ministério do Planejamento, Orçamento e Gestão, 2002. p.203-208.

BAUER, M.W., Análise de conteúdo clássica: uma revisão. In: Pesquisa qualitativa com texto, imagem e som: um manual prático. Tradução de Pedrinho Guareschi. Petrópolis - RJ: Vozes, 2002. cap 8.

BERTÓK, J; CADDY, J. e RUFFNER M. Fazendo Acontecer: Diretrizes de políticas voltadas à Responsabilização e à Transparência. In: FÓRUM NACIONAL SOBRE RESPONSABILIDADE E TRANSPARÊNCIA NO SETOR PÚBLICO.2001.Brasília.Anais... Ministério do Planejamento, Orçamento e Gestão, 2002, p.55-73.

BNDES. Banco Nacional de Desenvolvimento Econômico e Social. Terceiro Setor e desenvolvimento social. Relato Setorial $\mathbf{n}^{\circ}$ 3. Julho de 2001.

Disponível em:

$<$ http://www.bndes.gov.br/conhecimento/resposta tip.asp?publicacao=Relatos+Setor iais\&offset=40 >. Acesso em: 27 mar.2009.

BRASIL. Decreto $\mathbf{n}^{\circ}$ 6.170, de 25 de julho de 2007a. Disponível em:< https://www.convenios.gov.br/portal/arquivos/DECRETON61702007convenios.pdf > Acesso em: 24 abr.2009.

Decreto $\mathrm{n}^{\circ}$ 6.329, de 27 de dezembro de 2007b. Disponível em:< https://www.convenios.gov.br/portal/arquivos/DECRETON63292007CONVENIOS.pd f > Acesso em: 24 abr.2009.

Decreto ${ }^{\circ}$ 6.428, de 14 de abril de 2008a. Disponível em:< https://www.convenios.gov.br/portal/arquivos/DECRETON64282008convenios.pdf > Acesso em: 24 abr.2009.

Decreto $\mathrm{n}^{\circ}$ 6.497, de 30 de junho de 2008b. Disponível em:< https://www.convenios.gov.br/portal/arquivos/DECRETO 6497 20080630.pdf> Acesso em: 24 abr.2009. 
Decreto $n^{\circ}$ 6.619, de 29 de outubro de 2008c. Disponível em:< https://www.convenios.gov.br/portal/arquivos/DECRETO_6619_29-102008_Convenios.pdf > Acesso em: 24 abr.2009.

Instrução Normativa STN n $^{0} 1$ de 15 de janeiro de 1997. Disponível em: < http://www.tesouro.fazenda.gov.br/legislacao/download/contabilidade/IN1 97.pdf> Acesso em: 04 mai. 2009.

Lei $\mathbf{n}^{\circ} 101$, de 4 de maio de 2000. Disponível em: < http://www.planalto.gov.br/ccivil 03/Leis/LCP/Quadro Lcp.htm>. Acesso em: 04 mai. 2009.

. Lei $\mathbf{n}^{\circ} \mathbf{8 . 7 4 2}$, de 07 de dezembro de 1993. Disponível em:<https://www.convenios.gov.br/portal/arquivos/LEI 87421993 ORGANIZACAO ASSISTENCIA SOCIAL.pdf> Acesso em: 24 abr.2009.

Lei $\mathbf{n}^{\circ}$ 9.637, de 15 de maio de 1998. Disponível em: < https://www.planalto.gov.br/ccivil_03/LEIS/L9637.htm>. Acesso em: 02 fev. 2009.

. Ministério do Planejamento, Orçamento e Gestão. Indicadores e Métricas para Avaliação de E-serviços. Disponível em:

$<$ http://www.governoeletronico.gov.br/acoes-e-projetos/indicadores-e-metricas-paraavaliacao-de-e-servicos/?searchterm=indicadores $\% 20 \mathrm{e} \% 20 \mathrm{~m} \% \mathrm{C} 3 \%$ A9tricas.. Acesso em: 11 mai.2009a.

Ministério do Planejamento, Orçamento e Gestão. Manual de Cadastramento de Proponente. Portal dos Convênios. Disponível em: $<$ https://www.convenios.gov.br/portal/manuais/Manual_Usuario_Siconv_Cad_Prop_ Ent_Priv_SFL_versao_3.pdf> Acesso em: Acesso em: 24 abr.2009b.

Ministério do Planejamento, Orçamento e Gestão. Manual da Legislação Federal sobre Convênios da União. Portal dos Convênios. Disponível em: $<$ https://www.convenios.gov.br/portal/manuais/Manual Legislacao Convenio.pdf > Acesso em: 24 abr.2009c.

Ministério do Planejamento, Orçamento e Gestão. Manual de Orientações para Utilização do Siconv - Sistema de Gestão de Convênios. Portal dos Convênios. Proponente-Convente. Disponível em:

$<$ https://www.convenios.gov.br/portal/manuais/ORIENTACOES UTILIZACAO PORT AL CONVENENTE.pdf.> Acesso em: 24 abr.2009d. 
Ministério do Planejamento, Orçamento e Gestão. Portal dos Convênios.

Um novo Paradigma nas transferências voluntárias da União.

Disponível em:

<http://www.mp.gov.br/secretarias/upload/Arquivos/imprensa/pronunciamentos/apres entacoes/081110_APRE_Convenios_sp_Rogerio_santanna.pdf> . Acesso em: 24 abr. 2009e.

. Ministério do Planejamento, Orçamento e Gestão. Secretaria de Orçamento

Federal. Vinculações de receitas dos orçamentos fiscal e da seguridade social e o poder discricionário de alocação dos recursos do Governo Federal - v. 1, n.1. Brasília: Secretaria de Orçamento Federal - SOF, 2003.

Portaria Interministerial MP/MF/MCT N²4, de 19 de fevereiro de 2008d.

Disponível em:<

https://www.convenios.gov.br/portal/arquivos/Portarialnterministerial24-

2008ARQUIVAMENTO.pdf> Acesso em: 04 mai. 2009.

Portaria Interministerial $\mathbf{n}^{\circ} \mathbf{1 2 7}$, de 29 de maio de 2008e. Disponível em:<https://www.convenios.gov.br/portal/arquivos/Portarialnterministerial127-2008CONVENIOS.pdf.> Acesso em: 24 abr.2009.

. Portaria Interministerial $\mathbf{n}^{\circ} \mathbf{1 6 5}$, de 20 de junho de 2008f. Disponível em:< https://www.convenios.gov.br/portal/arquivos/PORTARIA 1652008 20062008.pdf>. Acesso em: 24 abr.2009.

Portaria Interministerial $\mathbf{n}^{0} \mathbf{3 4 2}$, de 5 de novembro de $2008 \mathrm{~g}$. Disponível em:<https://www.convenios.gov.br/portal/arquivos/Portaria 3425 novembro 2008. pdf>. Acesso em: 24 abr.2009.

. Portaria Interministerial $\mathbf{n}^{\circ}$ 404, de 23 de dezembro de 2008h. Disponível em:<https://www.convenios.gov.br/portal/arquivos/Portarialnterministerial404231220 08alteraportaria12729052008.pdf>. Acesso em: 24 abr.2009.

Secretaria do Tesouro Nacional. Mensagem 2009/0428959 da STN.

Disponível em: <https://www.convenios.gov.br/portal/avisos/comunica stn.pdf. > Acesso em: 24 abr.2009f

. Secretaria do Tesouro Nacional. Transferências Voluntárias. Disponível em:<http://www.tesouro.fazenda.gov.br/estados_municipios/transferencias_voluntari as.asp> Acesso em: 20 abr.2009g 
Tribunal de Contas da União. Acórdão n 788/2006-TCU-Plenário. 2006a Disponível em: <http://portal2.tcu.gov.br/portal/page/portal/TCU>. Acesso em: 24 abr.2009.

Tribunal de Contas da União. Acórdão n 2066/2006-TCU-Plenário. 2006b Disponível em: <http://portal2.tcu.gov.br/portal/page/portal/TCU>. Acesso em: 24 abr.2009.

. Tribunal de Contas da União. Convênios e outros repasses. 2. ed. Brasília: Secretaria-Geral de Controle Externo, 2008i.

BRESSER-PEREIRA, L. C. A reforma gerencial do Estado de 1995. Revista de Administração Pública, v. 34, n. 4, p. 7-26, jul. 2000.

COLAÇO-ALVES, M. F.; SODRE, A. C. . Transferências Intergovernamentais Voluntárias: Relações entre Emendas Parlamentares e Corrupção Municipal no Brasil. In: III ENCONTRO DE ADMINISTRAÇÃO PÚBLICA E GOVERNANÇA EnAPG, 2008, Anais...Salvador. CD-Room de Trabalhos Apresentados, 2008.

CGU. Portal da Transparência. Glossário. Disponível em:

http://www.portaldatransparencia.gov.br/glossario/DetalheGlossario.asp?letra=c. Acesso em: 14 abr. 2009

DAGNINO, E. Sociedade civil, participação e cidadania: de que estamos falando? In: Daniel Mato (Org.). Políticas de ciudadanía y sociedad civil en tiempos de globalización. Caracas: FACES, Universidad Central de Venezuela, p. 95-110.

FERREIRA, D.E.S. Experiências recentes de controle social sobre o processo de orçamentação pública municipal no Brasil. 2006. Monografia apresentada ao XI prêmio Tesouro Nacional - Secretaria do Tesouro Nacional Escola de Administração Fazendária, Brasília, 2006.

FERREIRA, I. F. S.; BUGARIN, M. S. Transferências voluntárias e ciclo políticoorçamentário no federalismo fiscal brasileiro. Rev. Bras. Econ. [online]. 2007, v. 61, no. 3, p. 271-300. ISSN 0034-7140.

FERREIRA, M. M.; FERREIRA, C. H. M. Terceiro Setor: um conceito em construção, uma realidade em movimento.In: SEMANA DO CONTADOR DE MARINGÁ, 2006, Maringá. Anais...,Maringá.2006. 
PUGLISI, M.L.;FRANCO, B. As categorias de análise. In: Análise de

Conteúdo. Brasilia: Líber Livro, 2003. cap. 6.

LÜDKE, M. e ANDRÉ M. E.D.A. Métodos de coleta de dados: observação, entrevista e análise documental. In: Pesquisa em educação: abordagens qualitativas.

São Paulo: EPU, 2005. cap.3

MACHADO, R. Estrutura Analítica de Projeto. Projeto Siconv. Mensagem recebida por<Aline.cabeceira@.gov.br > em 19 de mai. 2009.

MATIAS-PEREIRA, J. Sistema de controle na Administração Pública. In:

Curso de Administração Pública. São Paulo: Atlas, 2008. cap. 24 - 26.

MAIA, R. C.M., Redes Cívicas e Internet. In:EISENBERG, J.; CEPIK, M. (Org.). Internet e Política: Teoria e Prática da Democracia Eletrônica. Belo Horizonte: UFMG, 2002. p. 46-72.

MILANI, C. R. S. O princípio da participação social na gestão de políticas locais: uma análise de experiências latino-americanas e européias. Revista de Administração Pública, Rio de Janeiro,v. 42, n. 3, p. 551-579, 2008.

MODESTO, P. E. G. Reforma administrativa e marco legal das organizações sociais no Brasil: as dúvidas dos juristas sobre o modelo das organizações sociais. Revista do Serviço Público, Brasília, v. 2, n. 48, 27-57, mai./ago.1997.

NASSUNO, M.. Organização dos usuários, participação na gestão e controle das organizações sociais. Revista do Serviço Público, Brasília, v. 1, n. 48, 26-40, jan./abr.1997.

PAULA, A. P. P. Por uma nova gestão pública: limites e potencialidades da experiência contemporânea. Reimpressão. Rio de Janeiro: FGV, 2007.

PINTO, C. R. J. As ONGs e a Política no Brasil: Presença de Novos Atores. Revista de Ciências Sociais, Rio de Janeiro, v.49, N³ 2006 , p.651- 613.

RAMOS, M. de M. Contratos de Gestão: instrumento de ligação entre os setores do aparelho do Estado. Revista do Serviço Público, Brasília, v. 2, n. 48, 80-99, mai./ago.1997 
RIBEIRO, P.; SOPHIA, D. C.; GRIGÓRIO, D. A. Gestão governamental e sociedade: informação, tecnologia e produção científica. Ciência e Saúde Coletiva, Rio de Janeiro, v. 12, n. 3, p.623-631, 2007.

SÁ, E. N. de C.; RABELLO, M. C. G. Administração por convênios, um instrumento gerencial de políticas: uma análise dos convênios da secretaria de Estado da Saúde de São Paulo. Rev. Saúde Pública, São Paulo, v. 22, n. 2, p. 150-158, 1988.

SILVA, F. C. C. Controle Social: Reformando a administração para a Sociedade. In: Perspectivas para o Controle Social e a Transparência da Administração Pública - Prêmio Serzedello Corrêa, 2001, Brasília: TCU, 2001.

YIN, R. K.; Estudo de Caso: planejamento e métodos. 3. ed. Porto Alegre: Bookman, 2005. 